\title{
Occurrence, distribution and health risk assessment of potentially toxic elements in soil: A case study from semi-arid region of southwest Punjab, India.
}

Karanveer .

Panjab University

Ritu Bala

Panjab University

Debabrata Das ( $\nabla$ debabratadas@pu.ac.in )

Panjab University https://orcid.org/0000-0003-2374-462X

\section{Research Article}

Keywords: Soil Heavy metal, Agriculture pollution, Health Hazard, Potential Ecological risk, Source apportionment, South-west Punjab

Posted Date: January 21st, 2022

DOI: https://doi.org/10.21203/rs.3.rs-1283282/v1

License: (9) This work is licensed under a Creative Commons Attribution 4.0 International License. Read Full License 
1 Occurrence, distribution and health risk assessment of potentially toxic elements in soil:

2 A case study from semi-arid region of southwest Punjab, India.

3 Karanveer, Ritu Bala, Debabrata Das*

4 Department of Geology, Panjab University, Chandigarh

$5 \quad *$ Corresponding author: debabratadas@pu.ac.in 
6 Occurrence, distribution and health risk assessment of potentially toxic elements in soil:

7 A case study from semi-arid region of southwest Punjab, India.

8 Karanveer, Ritu Bala, Debabrata Das*

$9 \quad *$ Corresponding author: debabratadas@pu.ac.in

10 Abstract: Numerous groundwater studies exist on the heavy metal (HM) pollution in Punjab, however, research 11 is quite limited in the soil system of the region. In the current work, detailed study has been carried out on the 12 distribution of toxic metals in the agricultural and barren soil (AS \& BS) samples in the semi-arid region of Punjab. Pollution level of HMs was determined by using various pollution indices like geo-accumulation index (Igeo), enrichment factor (EF), pollution index and pollution load index (PLI), and potential ecological risk assessment (PERI). A total of 11 toxic elements were measured and 2 fold values were observed in the AS samples. Range of HMs in the AS samples were 3.9 - 28.1, 29.2 - 90, 6.7 - 32.8, 4.2 - 65.6, 13019.5 - 43900, 95.7 - 553, 13.1 42.1, 16.5 - 25.2, 82 - 267, 25 - 78.6, $25.4-131.8 \mathrm{mg} / \mathrm{kg}$ for As, $\mathrm{Cr}, \mathrm{Cu}, \mathrm{Co}, \mathrm{Fe}, \mathrm{Mn}, \mathrm{Ni}, \mathrm{Pb}, \mathrm{Sr}, \mathrm{V}$ and $\mathrm{Zn}$ respectively. It is seen that there is high variability in the spatial distribution of metals throughout the region indicating the role of anthropogenic activities. Pollution levels reveal the studied region to be moderately contaminated in terms of anthropogenic pollution. Multivariate statistical analysis results also revealed that the majority of HM pollution in the region is due to anthropogenic activities with few elements to be of geogenic origin. Potential health risks assessment is carried out and total hazard index (HI) values were in the acceptable range but the total cancer risks were comparatively higher for children than adults. This study shows the risk of heavy metal contamination in the agricultural regions and the results obtained have global implications. Keywords: Soil Heavy metal, Agriculture pollution, Health Hazard, Potential Ecological risk, Source apportionment, South-west Punjab.

\section{Introduction}

Soil is considered to be a fundamental basis for human survival, habitation, and social development (Wei-Xin et al., 2008; Wong et al., 2002). From the last few decades with the rapid expansion of industrialization and anthropogenic activities, heavy metals (HMs) presence in the surface sediments have emerged as a matter of global concern and is growing progressively. This is due to the high toxicity and non-biodegradable nature of heavy metals and once they enter the soil system it takes a long time to eliminate (Alloway, 2012). In general, metals whose density is greater than $5 \mathrm{gm} / \mathrm{cm}^{3}$ are categorized as heavy metals in the environment (Darwesh \& Matter, 2021). Heavy metal cumulation in the soil affects the environment and human health by transfer through food chain (Bhaskar et al., 2010; Rong et al., 2016). Crops that are grown on the contaminated soil have a tendency to incorporate heavy metals into them and thus act as a direct pathway for transmission of these elements to the humans (Kulhari et al., 2013; Rattan et al., 2005). Exposure to the heavy metals can be hazardous to human health even at very low concentration and is a cause of many life threatening diseases such as cancer, atherosclerosis, Parkinson's and Alzheimer's (Burges et al., 2015; Muszynska \& Hanus-Fajerska, 2015). Also, exposure to the HMs at high level can result in permanent disabilities, including various reading or learning disabilities, loss of hearing, visual function disruption, problem of behaviour and attention (Sarkar, 2002). and thus reduces the land arability. Heavy metal distribution is related to the type of land use, physico-chemical properties of soil and the irrigation type in agriculture (Liyuan et al., 2003). In general both geogenic and 
anthropogenic activities are accountable for the existence of the heavy metal in nature. Anthropogenic events such as application of pesticides, fertilizers and waste disposal, play a key role in the accumulation of these metals in the soil profile (Castro-González et al., 2017; Chen et al., 2015; Liu et al., 2016). Various studies have been carried worldwide to understand the extent of heavy metal contamination and understand the role of different anthropogenic activities on the soil contamination (Chen et al., 2015; Jiang et al., 2017; Yang et al., 2018; Proshad et al., 2019; Wu et al., 2021). Heavy metal pollution is a serious and widespread issue in the developing countries such as India due to less strict rules and regulations on anthropogenic activities.

Punjab lying in the northwest part of country was the base of green revolution in 1960s and is proudly known as the grain basket of India. However this fame has resulted in degradation of its soil quality with the presence of heavy metal content higher than the permissible limits. Among all the heavy metals $\mathrm{As}, \mathrm{Cr}, \mathrm{Cd}$ and $\mathrm{Ni}$ are considered as group 1 carcinogens (IARC, 2012). Cancer cases has increased in the current region of Punjab from past few decades (SINGLA et al., 2021) and thus increases the importance of studying the pollution level of these metals. Current study area is among one of the regions that has experienced intensive agriculture since the beginning of civilization. Detailed study of heavy metal pollution in soil of region is limited and assessment of health has also not been undertaken in the current study region.

Hot-spot areas and source identification is essential for the management of heavy metal pollution and study of spatial distribution patterns helps in achieving the goal (Imperato et al., 2003; Lee et al., 2006; Li et al., 2004). Multivariate statistical analysis like correlation and factor analysis are also used worldwide by various researchers to determine possible source of HM pollution (Ennaji et al., 2020; Tian et al., 2017; Zhuang et al., 2020). Due to aforementioned, this study is undertaken with an aim to (i) determine the content and spatial distribution pattern of heavy metals in surface sediments of the region (ii) estimate the pollution levels and potential ecological risk of HMs (iii) investigate the potential health risk posed to human beings (iv) identify source of HM by utilizing multivariate statistical analysis. The obtained results are useful for the mitigation of heavy metal pollution, for better management policies and to protect the human beings exposed to higher levels of contaminants.

\section{Materials and Methods}

\section{Study area}

The study region lies in the Punjab state of north-western India (Fig. 1). It is among one of the most productive agricultural regions and has been contributing about $25-50 \%$ of rice and $38-75 \%$ of wheat to the food reserves of India during the last four decades (Singh \& Park, 2018). Geographically, the Punjab state is divided into 3 zones i.e. Malwa, Majha and Doaba. Current study region covering an area of $1351.7 \mathrm{~km}^{2}$ belongs to the Barnala district of Malwa region $\left(30^{\circ}\right.$ to $\left.30^{\circ} 52^{\prime} \mathrm{N} ; 7^{\circ} 15^{\prime} 75^{\circ} \mathrm{E}\right)$ and has a population of 190685 as per census of 2011 . Agriculture is the main occupation of people with wheat, paddy and cotton as main crops grown in the area. Two well-known industries of textiles and combines is also present in the urban part of the district. Climate of the region is generally semi-arid with an average rainfall of 420mm (CGWB, 2017). Geologically area forms part of Indo-Gangetic alluvial deposits of quaternary age (Singh et al., 2015) and is mainly composed of sands of various grades, clays and silts. Kankar in the form of sheet deposits or in nodular form is present at the depth of $0.75 \mathrm{~cm}$ to $2 \mathrm{~m}$ below the surface. Soil of the district is loamy sand along with sandy loam kaller spotted at few places (CGWB, 2017). 


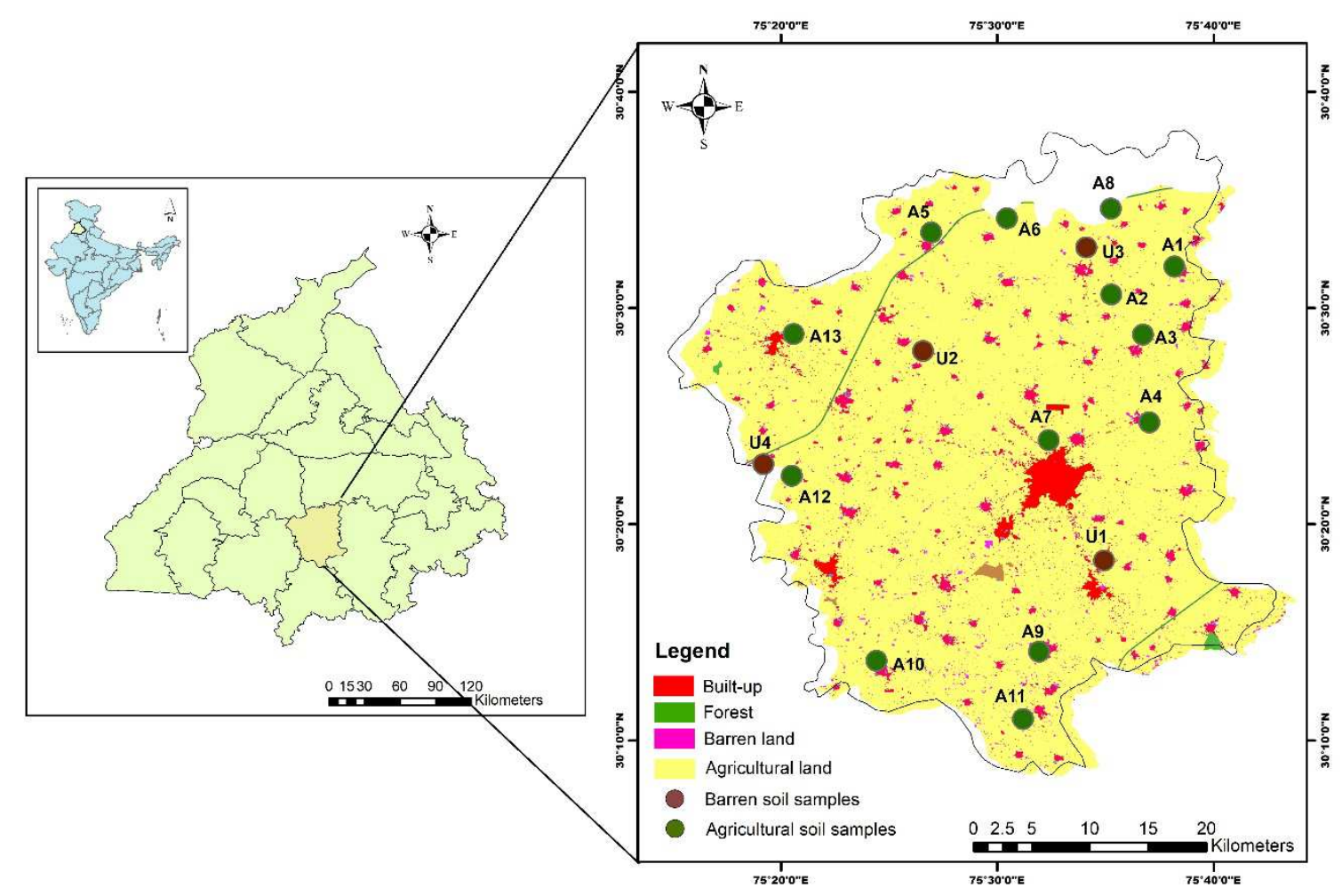

Fig. 1 Study area location, land use and sampling sites

\section{Sample Collection \& Analysis}

For the present work 17 sampling sites were selected from the agricultural land and barren areas on the basis of the systematic sampling strategy. Each sample was collected on the basis of grid pattern covering the entire district. Barren areas are those that has been largely unaffected by any of the anthropogenic activity. Detailed information of sampling sites as per their land-use is given in Fig. 1 \& Table $\underline{1}$ along with their geographical coordinates. Composite soil sample of around $1 \mathrm{~kg}$ was collected from each site using a stainless steel auger. Collected samples were tightly packed in double zip plastic bags (pre cleaned with double distilled water) and transported to the laboratory. Sample preparation is carried out by following the EPA method 3050B (EPA, 1996). Samples were oven dried in the laboratory until all the moisture content was driven out. After complete drying each sample was passed though $2 \mathrm{~mm}$ polyethylene sieve to remove any of the plant roots or other coarser material present. Subsample of the dried soil was homogenized by using mechanical agate mortar and fine particles $(<200$ $\mu \mathrm{m})$ were obtained for heavy metal analysis.

Strong acid digestion procedure $\left(\mathrm{HNO}_{3}\right.$ : $\mathrm{HCL}$ : $\left.\mathrm{HF}\right)$ was employed for the complete decomposition and extraction of HMs on a hot plate. After the complete digestion, samples were filtered and final volume of $50 \mathrm{ml}$ was obtained with ultra-pure distilled water. The HM analysis was carried out by using triple quadropole inductively coupled plasma mass spectrophotometer (ICP-MS). High grade reagents, pre-cleaned glassware and ultra-pure de-ionised water was used for the analysis. For quality assurance and quality control (QA/QC) purpose certified reference material (CRM), duplicates and blank were used to check the analytical instrument. Results of CRM were within the uncertainty range of reference values. Relative standard deviation (RSD) of duplicate samples were $<5 \%$. The $\mathrm{pH}$ of the collected soil samples was estimated in Soil: water (1:5) suspension by using the Hanna bench top pH meter. 
Table 1 Details of AS and BS sampling locations $(n=17)$

\begin{tabular}{llcl}
\hline S. No. & Location name & Latitude & Longitude \\
\hline & & Agricultural Soil (n=13) & \\
\hline 1 & Kurar & 30.53 & 75.63 \\
2 & Khiali & 30.51 & 75.58 \\
3 & Hamidi & 30.47 & 75.61 \\
4 & Karamgarh & 30.41 & 75.61 \\
5 & Gehla & 30.55 & 75.45 \\
6 & Dhaner & 30.56 & 75.50 \\
7 & Sanghera & 30.40 & 75.54 \\
8 & Dadhahur & 30.57 & 75.58 \\
9 & Bhadur & 30.48 & 75.34 \\
10 & Pakhokhalan & 30.22 & 75.40 \\
11 & Daraj & 30.36 & 75.34 \\
12 & Kaleke & 30.23 & 75.53 \\
13 & Kotduna & 30.18 & 75.51 \\
\hline & & Barren Soil (n=4) & \\
\hline 14 & Dhanula & 30.30 & 75.58 \\
15 & Bhotna & 30.46 & 75.44 \\
16 & Kalala & 30.54 & 75.56 \\
17 & Balloke & 30.37 & 75.32 \\
\hline
\end{tabular}

107

Statistical analysis

Multivariate statistical analysis were applied to explore the relationship among heavy metals. Pearson's correlation analysis and Box plot were prepared using the Minitab18 software to determine the possible correlations between the different heavy metals. SPSS software is used to obtain the Principal Component Analysis (PCA) and cluster analysis so as to determine the correlation and potential source of HMs. For the demarcation of hotspots area of the contamination, spatial distribution maps of different heavy metal were prepared using the inverse distance weight (IDW) technique in GIS software (ArcGIS, version 10.3).

\section{Soil Contamination Evaluation}

Pollution assessment in soils is crucial as exposure to the excessive amounts of heavy metal can cause adverse health effects accompanied by ecotoxicity. Advancement of different soil indices such as geo-accumulation index $\left(\mathrm{I}_{\mathrm{Geo}}\right)$, enrichment factor $(\mathrm{EF})$, pollution index (PI), pollution load index (PLI) and potential ecological risk index (PERI) helps in determining the contamination effect and toxicity of heavy metals in soil.

Geochemical baseline plays vital role in identifying the natural and anthropogenic sources of these metals in soil.

Due to the lack of background data in this study region, metal concentration of barren land is utilized as the baseline concentration in this study. These are the sites unaffected by any of the urban, industrial or agricultural activities and thus can be utilized for measuring pollution levels.

Geo-accumulation Index ( $\left.\mathrm{I}_{\mathrm{geo}}\right)$

Geo-accumulation index is widely used to quantify the extent of environmental pollution. It reflects the amount of heavy metal absorption in soil and was determined by using the following equation (Muller, 1979).

$$
\mathrm{I}_{\text {geo }}=\log _{2}\left(\mathrm{C}_{\mathrm{i}} / 1.5 * \mathrm{~B}_{\mathrm{i}}\right)
$$

Where $\mathrm{C}_{\mathrm{i}}$ represents the concentration of heavy metal in the soil sample and $\mathrm{B}_{\mathrm{i}}$ indicates the baseline concentration of metal. To minimize the effect of fluctuations in background value due to changes in lithology, constant 1.5 is used (Loska et al., 2004; Solgi et al., 2012). Level of contamination is classified into seven classes (I-VII) as given in Table 2 (Bhuiyan et al., 2010).

Enrichment Factor (EF) 
133

134

135

136

137

138

139

140

141

142

143

144

145

146

147

148

149

150

151

152

153

For the enrichment factor calculation, normalization is done with the reference element. Fe, $\mathrm{Al}, \mathrm{Mn}$ and $\mathrm{Ti}$ are generally considered as reference elements (Cheng et al., 2018). Iron being a conservative element is used in various studies and is also chosen for reference in the current study. The EF was calculated by utilizing the following equation.

$$
\mathrm{EF}=\left(\mathrm{C}_{\mathrm{i}} / \mathrm{Bn}_{\mathrm{S}}\right) /\left(\mathrm{B}_{\mathrm{i}} / \mathrm{Bn}_{\mathrm{B}}\right)
$$

Where $\mathrm{C}_{\mathrm{i}}$ and $\mathrm{Bn}_{\mathrm{s}}$ are the heavy metal and background element (Iron) concentration in the sample. $\mathrm{B}_{\mathrm{i}}$ and $\mathrm{Bn}_{\mathrm{B}}$ is the heavy metal and background concentration in the uncontaminated background samples. Categorization of soils on the basis of EF is given by in Table 2 (Sutherland, 2000; Zahran et al., 2015).

Pollution Index (PI) and Pollution Load Index (PLI)

These are important to identify the presence of anthropogenic contamination in the surface soil. Pollution index (PI) or contamination factor $\left(\mathrm{C}_{\mathrm{f}}\right)$ is the contamination index of single heavy metal (Khorshid \& Thiele-Bruhn, 2016) and is calculated as:

$$
P I=\frac{\text { Content of heavy metal in sample }}{\text { Geochemical baseline concentration of metal }}
$$

Results obtained for the pollution index were interpreted on the basis of classification proposed by (Tomlinson et al., 1980) (Table 2).

Pollution Load Index determines the pollution level in the area as combined effect of all the heavy metals and is represented as following (Tomlinson et al., 1980):

$$
\text { PLI }=\sqrt[n]{C_{1} \times C_{2} \times C_{3} \times \ldots \ldots \ldots \ldots \ldots \ldots C_{n}}
$$

Where $\mathrm{n}$ is the number of heavy metals studied and $\mathrm{C}_{\mathrm{f}}$ represents the contamination factor of single metal.

\begin{tabular}{|c|c|c|c|c|c|c|c|}
\hline $\mathrm{I}_{\mathrm{geo}}$ & Classification & EF & Classification & PI & Classification & PLI & Classification \\
\hline$<0$ & Uncontaminated & $<2$ & $\begin{array}{l}\text { Deficiency to } \\
\text { minimal } \\
\text { enrichment }\end{array}$ & $<1$ & $\begin{array}{l}\text { Low } \\
\text { contamination }\end{array}$ & $<1$ & Low pollution \\
\hline $0 \leq 1$ & $\begin{array}{l}\text { Uncontaminated to } \\
\text { moderately } \\
\text { contaminated }\end{array}$ & $2 \leq 5$ & $\begin{array}{l}\text { Moderate } \\
\text { enrichment }\end{array}$ & $1 \leq 3$ & $\begin{array}{l}\text { Moderate } \\
\text { contamination }\end{array}$ & $1 \leq 2$ & $\begin{array}{l}\text { Moderate } \\
\text { pollution }\end{array}$ \\
\hline $1 \leq 2$ & $\begin{array}{l}\text { Moderately } \\
\text { contaminated }\end{array}$ & $5 \leq 20$ & $\begin{array}{l}\text { Significant } \\
\text { enrichment }\end{array}$ & $3 \leq 6$ & $\begin{array}{l}\text { Considerable } \\
\text { contamination }\end{array}$ & $2 \leq 5$ & High pollution \\
\hline $2 \leq 3$ & $\begin{array}{l}\text { Moderately } \\
\text { strongly } \\
\text { contaminated }\end{array}$ & $20 \leq 40$ & $\begin{array}{l}\text { Very high } \\
\text { enrichment }\end{array}$ & $\geq 6$ & $\begin{array}{l}\text { Very high } \\
\text { contamination }\end{array}$ & $\geq 5$ & $\begin{array}{l}\text { Extremely high } \\
\text { pollution }\end{array}$ \\
\hline $3 \leq 4$ & $\begin{array}{l}\text { Strongly } \\
\text { contaminated }\end{array}$ & $\geq 40$ & $\begin{array}{l}\text { Extremely high } \\
\text { enrichment }\end{array}$ & & & & \\
\hline $4 \leq 5$ & $\begin{array}{l}\text { Strongly } \\
\text { extremely } \\
\text { contaminated }\end{array}$ & & & & & & \\
\hline$\geq 6$ & $\begin{array}{l}\text { Extremely } \\
\text { contaminated }\end{array}$ & & & & & & \\
\hline
\end{tabular}
Pollution levels are classified into four classes based on PLI values (Table 2).

Table 2 Index Classification for Soil contamination evaluation; $\mathrm{I}_{\text {geo, }}$ EF, PI and PLI Potential Ecological Risk Assessment (PERI)

156 It defines the threat of multi-metals to organisms in contaminated areas (Hakanson, 1980). This expression not only defines the HM pollution status in the sediments but also provides cumulative effect of environment and ecology with toxicity. PERI is expressed as:

$$
\mathrm{E}_{\mathrm{r}}^{\mathrm{i}}=\left(\mathrm{T}_{\mathrm{r}}^{\mathrm{i}} \times \mathrm{C}_{\mathrm{f}}\right)
$$


Where $\mathrm{C}_{\mathrm{f}}$ represents the contamination factor of metal, $\mathrm{T}_{\mathrm{r}}$ is the biological toxicity response factor and is taken as 5 for $\mathrm{Cu}, \mathrm{Pb}$ and Ni, 1 for Zn, 2 for Cr, V 10 for As (Hakanson, 1980; Zhang et al., 2014; Zhu et al., 2013). $\mathbf{E r}^{\mathbf{i}}$ indicates the potential ecological risk of each metal and RI is the combined effect of studied metals. RI is classified into four types on the basis of ecological risk: Low ecological risk $(<150)$, Moderate risk (150-300), Considerable risk (300-600) and very high risk (>600) (Hakanson, 1980).

\section{Health Risk Assessment}

Health risk assessment is calculated to determine the health risk posed to human beings through the exposure of different metals (NRC, 1983). In the current study Hazard quotient (HQ) and cancer risk (CR) were calculated to estimate non-carcinogenic and carcinogenic health risk respectively (USEPA, 2011). Dermal, Inhalation and Ingestion are three principal pathway of through which humans are exposed to soil pollution (USEPA, 1997; 2002; 2016).

Assessment of Non-carcinogenic risk

Average Daily Dose (ADD) in $\mathrm{mg} / \mathrm{kg} /$ day is calculated for each pathway using the following equations (USEPA, 2002):

5

$$
\begin{gathered}
\mathrm{ADD}_{\text {Ingestion }}=\mathrm{C} \times \frac{\mathrm{IR}_{\text {Ingestion }} \times \mathrm{EF} \times \mathrm{ED}}{\mathrm{BW} \times \mathrm{AT}} \times \mathrm{CF} \\
\mathrm{ADD}_{\text {Dermal }}=\mathrm{C} \times \frac{\mathrm{SA} \times \mathrm{AF} \times \mathrm{ABS} \times \mathrm{EF} \times \mathrm{ED}}{\mathrm{BW} \times \mathrm{AT}} \times \mathrm{CF} \\
\mathrm{ADD}_{\text {Inhalation }}=\mathrm{C} \times \frac{\mathrm{IR}_{\text {Inhale }} \times \mathrm{EF} \times \mathrm{ED}}{\mathrm{BW} \times \mathrm{AT} \times \mathrm{PEF}}
\end{gathered}
$$

Where $\mathrm{C}$ is the heavy metal concentration in the soil $(\mathrm{mg} / \mathrm{kg})$, $I R_{\text {Ingestion }}$ and $\mathrm{IR}_{\text {Inhale }}$ stands for ingestion rate (200 $\mathrm{mg} /$ day for children, $100 \mathrm{mg} /$ day for adult) and inhalation rate $\left(5 \mathrm{~m}^{3} /\right.$ day for children, $15 \mathrm{~m}^{3} /$ day for adult), respectively. EF represents exposure frequency and is taken as 365 days/year, ED indicates exposure duration (6 and 30 year for children and adult respectively) (USEPA, 2002), BW is body weight (20 kg for children and 70 $\mathrm{kg}$ for adult) (Adimalla, 2020b), and AT stands for average time period and is calculated as $70 \times 365$ days in case of carcinogenic and $\mathrm{ED} \times 365$ for non-carcinogenic health risk. DAF is dermal absorption factor 0.001 . SAF is skin adherence factor $\left(0.2 \mathrm{mg} / \mathrm{cm}^{2}\right.$ for children and $0.7 \mathrm{mg} / \mathrm{cm}^{2}$ for adult). PEF is particle emission factor and is $1.36 \times 10^{9}$. CF represents the conversion factor $\left(1 \times 10^{-6} \mathrm{~kg} / \mathrm{mg}\right)($ USEPA, 2002).

Hazard Quotient (HQ) estimates the non-carcinogenic risk of each metal and for each pathway and is the ratio of ADD to Rfd (USEPA, 2002).

$$
\mathrm{HQ}=\frac{\mathrm{ADD}}{\mathrm{Rfd}}
$$

Where ADD stands for average daily dose via ingestion, inhalation and dermal contact. Rfd is the reference dose and is given in Table $\underline{3}$ (Adimalla, 2020a).

Table 3 Reference dose of heavy metals via ingestion, inhalation and dermal pathways

\begin{tabular}{lllllll}
\hline & $\mathrm{As}$ & $\mathrm{Cr}$ & $\mathrm{Cu}$ & $\mathrm{Ni}$ & $\mathrm{Pb}$ & $\mathrm{Zn}$ \\
\hline $\mathrm{Rfd}_{\text {Ingestion }}$ & $3.00 \mathrm{E}-04$ & $3.00 \mathrm{E}-03$ & $4.00 \mathrm{E}-02$ & $2.00 \mathrm{E}-02$ & $1.40 \mathrm{E}-03$ & $3.00 \mathrm{E}-01$ \\
$\mathrm{Rfd}_{\text {Inhalation }}$ & $1.23 \mathrm{E}-04$ & $2.86 \mathrm{E}-05$ & $4.00 \mathrm{E}-02$ & $2.06 \mathrm{E}-02$ & $3.53 \mathrm{E}-03$ & $3.00 \mathrm{E}-01$ \\
$\mathrm{Rfd}_{\text {Dermal }}$ & $1.23 \mathrm{E}-04$ & $3.00 \mathrm{E}-03$ & $1.20 \mathrm{E}-02$ & $5.40 \mathrm{E}-03$ & $5.24 \mathrm{E}-04$ & $6.00 \mathrm{E}-02$ \\
\hline
\end{tabular}


194 Non-carcinogenic cumulative effect of a heavy metal via various pathways is expressed as Hazard Index (HI)

195 (USEPA, 2002). It is expressed by equation:

196

197

198

199

200

201

202

203

204

205

206

207

208

209

210

211

212

213

214

215

216

217

218

219

220

221

222

223

224

225

226

227

228

229

230

$$
\mathrm{HI}=\sum \mathrm{HQ}
$$

No health risk is observed for value less than unity, HI exceeding 1 signifies serious health concern (USEPA, 2001).

Assessment of Carcinogenic risk

Carcinogenic risk (CR) is calculated using the equation:

$$
\mathrm{CR}=\mathrm{ADD} \times \mathrm{Sf}
$$

Where $\mathrm{Sf}$ is the key factor called carcinogenic slope factor $(\mathrm{mg} / \mathrm{kg} / \mathrm{day})$ for single metal of concern. $\mathrm{Sf}_{\text {Ingestion }}$ (As $=1.50 \mathrm{E}+00, \mathrm{Cr}=5.01 \mathrm{E}-01, \mathrm{Ni}=1.70 \mathrm{E}+00), \mathrm{Sf}_{\text {Inhalation }}(\mathrm{As}=4.30 \mathrm{E}-03, \mathrm{Cr}=4.20 \mathrm{E}+01, \mathrm{Ni}=6.3 \mathrm{E}+00) \mathrm{Sf}_{\text {Dermal }}$ $(\mathrm{As}=3.66 \mathrm{E}+00, \mathrm{Cr}=2.00 \mathrm{E}+01, \mathrm{Ni}=4.25 \mathrm{E}+01) . \mathrm{CR}$ values between $10^{-6}$ to $10^{-4}$ are considered as safe (USEPA, 2002), CR values greater than $10^{-4}$ poses cancer risk (USEPA, 1989). TCR stands for the total carcinogenic risk that is the cumulative effect of $\mathrm{CR}$ via three pathways for a single heavy metal and is expressed as:

$$
\mathrm{TCR}=\sum \mathrm{CR}
$$

\section{Results \& Discussion}

Distribution of metal concentration

Table 4 presents the minimum, mean, median, maximum and standard deviation of each heavy metal analysed in top soil of Agricultural and Barren sites. Metal concentration of Indian natural background, World Health Organization (WHO) and European Union (EU) are used to facilitate the comparison. Mean concentration of $\mathrm{Cu}$, $\mathrm{Pb}, \mathrm{Mn}$, and $\mathrm{Zn}$ were found to be higher than the Indian natural background value (Gowd et al., 2010; Kuhad et al., 1989). However, the maximum concentration of $\mathrm{Ni}$, Fe and Co was about 1.5, 1.3, and 4.3 times higher than their natural background value in soil. When compared to the limits given by European Union, maximum concentration of As (28.1) and $\mathrm{Cu}$ (32.8) exceeds the limit of $20 \mathrm{mg} / \mathrm{kg}$ and $30 \mathrm{mg} / \mathrm{kg}$ (Krishna \& Govil, 2007). About $30 \%$ of sample exceeds the prescribed limit provided of World Health Organization (WHO, 2004) and Agency for Toxic Substances and Disease Registry (ATSDR, 2004) in case of Manganese and Cobalt.

Broad variation is observed in the mean concentration of HMs in the agricultural and barren areas in the present study. Total mean concentration of metals was in the order of: $\mathrm{Fe}>\mathrm{Mn}>\mathrm{Sr}>\mathrm{Cr}>\mathrm{Zn}>\mathrm{V}>\mathrm{Ni}>\mathrm{Co}>\mathrm{Pb}>\mathrm{Cu}>\mathrm{As}$ in the agricultural areas and $\mathrm{Fe}>\mathrm{Mn}>\mathrm{Sr}>\mathrm{V}>\mathrm{Zn}>\mathrm{Cr}>\mathrm{Co}>\mathrm{Ni}>\mathrm{Pb}>\mathrm{Cu}>\mathrm{As}$ in the barren land sites.

Results show the uniform order of HMs at both the areas (AS \& BS) with an exception of Cr, V, Ni and Co. However double fold values are found for all the metals in the samples from agricultural areas. Principal factors controlling the heavy metal concentration in soil are composition of parent rock, infiltration of contaminated water for irrigation and different types of agrochemicals used in the field to increase the crop productivity (Bhatti, Sambyal, et al., 2016). Among all the metals in the analyzed samples maximum value found was of Iron (Fe) and the high Fe content could be due to the natural abundance in parent rocks (Chandrasekaran et al., 2015). Higher value of other metals in the agriculture land is mainly associated with the anthropogenic input. Long term application of chemical Fertilizers, pesticides, fungicides, agriculture waste could be the reason for the higher value in the agricultural samples. Different NPK fertilizers are consider as a source of heavy metals such as As, 
$231 \mathrm{~Pb}, \mathrm{Cr}, \mathrm{Ni}, \mathrm{Cu}$ (Bhatti, Sambyal, et al., 2016). Soil $\mathrm{pH}$ of the samples is alkaline in nature with an average value

232 of 8.27 and thus results in decreased mobility of heavy metals (Kumar et al., 2019; Tian et al., 2017).

233 Heavy metal concentration is compared with various studies carried out globally and in other parts of Punjab and

234 results are presented in table $\underline{5}$. Majority of the metals show elevated level as compared to the other parts of Punjab

235 and surrounding areas.

236 Table 4 Statistical summary of element concentration $(\mathrm{mg} / \mathrm{kg})$ in AS \& BS samples

\begin{tabular}{|c|c|c|c|c|c|c|c|c|c|c|c|}
\hline \multicolumn{12}{|c|}{ Agricultural land $(n=13)$} \\
\hline Variable & As & $\mathrm{Cr}$ & $\mathrm{Cu}$ & Co & $\mathrm{Fe}$ & $\mathrm{Mn}$ & $\mathrm{Ni}$ & $\mathrm{Pb}$ & $\mathrm{Sr}$ & $\mathrm{V}$ & $\mathrm{Zn}$ \\
\hline Minimum & 3.9 & 29.2 & 6.7 & 4.2 & 13019.5 & 95.7 & 13.1 & 16.5 & 82 & 25 & 25.4 \\
\hline Median & 8.8 & 62.8 & 17 & 11.4 & 27031.23 & 429.2 & 30.2 & 19.2 & 125 & 59.9 & 48 \\
\hline Mean & 9.9 & 64.8 & 17.1 & 25.2 & 25722.6 & 364.4 & 27.6 & 19.3 & 139.4 & 55.2 & 55.7 \\
\hline Maximum & 28.1 & 90 & 32.8 & 65.6 & 43900 & 553 & 42.1 & 25.2 & 267 & 78.6 & 131.8 \\
\hline $\mathrm{SD}$ & 6 & 16.05 & 6.7 & 23.1 & 7630.8 & 161.7 & 9.4 & 2.1 & 52.5 & 17.8 & 26.9 \\
\hline \multicolumn{12}{|c|}{ Barren land $(n=4)$} \\
\hline Variable & As & $\mathrm{Cr}$ & $\mathrm{Cu}$ & Co & $\mathrm{Fe}$ & $\mathrm{Mn}$ & $\mathrm{Ni}$ & $\mathrm{Pb}$ & $\mathrm{Sr}$ & $\mathrm{V}$ & $\mathrm{Zn}$ \\
\hline Minimum & 3.5 & 29.9 & 6.3 & 3.9 & 11535.2 & 128 & 11.7 & 15.4 & 69 & 32.7 & 22.4 \\
\hline Median & 6.1 & 37.3 & 9.7 & 34.5 & 18083.3 & 251.2 & 15.7 & 18.2 & 95 & 40 & 35.1 \\
\hline Mean & 5.6 & 36.9 & 9.1 & 35.9 & 16750.5 & 240.9 & 15.2 & 18.6 & 96 & 39 & 32.9 \\
\hline Maximum & 6.9 & 43 & 10.8 & 70.6 & 19300 & 333 & 17.7 & 22.8 & 125 & 43.5 & 39.1 \\
\hline SD & 1.6 & 5.7 & 2 & 35.6 & 3661 & 91.1 & 2.5 & 3.6 & 27.6 & 4.5 & 7.3 \\
\hline
\end{tabular}

237 SD, Standard Deviation

238

239

\begin{tabular}{|c|c|c|c|c|c|c|c|c|c|c|c|c|}
\hline City/Country & As & $\mathrm{Cr}$ & $\mathrm{Cu}$ & $\mathrm{Co}$ & $\mathrm{Fe}$ & $\mathrm{Mn}$ & $\mathrm{Ni}$ & $\mathrm{Pb}$ & $\mathrm{Sr}$ & $\mathrm{V}$ & $\mathrm{Zn}$ & References \\
\hline $\begin{array}{c}\text { Puebla and } \\
\text { Tlaxcala, } \\
\text { Mexico }\end{array}$ & 5.3 & 17.6 & 13.1 & 5.5 & - & - & 14.8 & 14.7 & - & - & 22.8 & $\begin{array}{l}\text { (Castro-González } \\
\text { et al., 2017) }\end{array}$ \\
\hline $\begin{array}{c}\text { Tarutia, } \\
\text { Bangladesh }\end{array}$ & 4.7 & 6.7 & 24.6 & - & - & - & - & 19.9 & - & - & - & $\begin{array}{l}\text { (Proshad et al., } \\
\text { 2019) }\end{array}$ \\
\hline Xiangfen, China & 14 & 71 & 30 & - & - & - & 32 & 24 & - & - & 83 & (Pan et al., 2016) \\
\hline Quzhou, China & 9.2 & 29.5 & 17.5 & & & & 24.7 & 16 & & & 61.1 & $\begin{array}{c}\text { (Zhuang et al., } \\
\text { 2020) }\end{array}$ \\
\hline Tehran, Iran & - & - & 36 & 13.2 & - & - & 36.9 & 16.4 & - & - & 217 & $\begin{array}{c}\text { (Hani \& Pazira, } \\
\text { 2011) }\end{array}$ \\
\hline $\begin{array}{l}\text { Peloponnese, } \\
\text { Greece }\end{array}$ & 6.9 & 83.1 & 74.6 & 21.9 & $2.65 \%$ & 1020 & 146.8 & 19.7 & - & - & 74.8 & (Kelepertzis, 2014) \\
\hline
\end{tabular}




\begin{tabular}{|c|c|c|c|c|c|c|c|c|c|c|c|c|}
\hline $\begin{array}{l}\text { Tadla plain, } \\
\text { Morocco }\end{array}$ & - & 32.7 & 138.1 & - & 19249 & - & - & 31.7 & . & - & 162.1 & $\begin{array}{c}\text { (Ennaji et al., } \\
2020)\end{array}$ \\
\hline $\begin{array}{c}\text { Indian natural } \\
\text { background }\end{array}$ & - & 114 & 56.5 & 15.2 & 32015 & 209 & 27.7 & 13.1 & - & - & 22.1 & $\begin{array}{l}\text { (Gowd et al., 2010; } \\
\text { Kuhad et al., 1989) }\end{array}$ \\
\hline
\end{tabular}

\begin{tabular}{|c|c|c|c|c|c|c|c|c|c|c|c|c|}
\hline $\begin{array}{l}\text { Harikewetland,P } \\
\text { unjab }\end{array}$ & - & $21-75$ & $13-25$ & $\begin{array}{l}0.1- \\
3.8\end{array}$ & - & - & & $2.8-9.1$ & - & - & - & $\begin{array}{l}\text { (Bhatti, Sambyal, } \\
\text { et al., 2016) }\end{array}$ \\
\hline $\begin{array}{c}\text { Amritsar and } \\
\text { Tarn Taran, } \\
\text { Punjab }\end{array}$ & - & 21.25 & 20.70 & 5.17 & 13832 & - & - & 5.86 & - & - & 360.28 & $\begin{array}{l}\text { (Bhatti, Kumar, et } \\
\text { al., 2016) }\end{array}$ \\
\hline Fazilka, Punjab & 10 & & & & & & 26 & 8 & & & 57.9 & $\begin{array}{c}\text { (Narang et al., } \\
2018 \text { ) }\end{array}$ \\
\hline $\begin{array}{c}\text { Fatehgarh sahib } \\
\text { Punjab }\end{array}$ & 2.6 & 24.1 & 16.5 & 9.4 & 9044 & 257.6 & - & 7.8 & - & - & 26.8 & $\begin{array}{l}\text { (Kumar et al., } \\
2020)\end{array}$ \\
\hline Barnala, Punjab & $\begin{array}{l}3.9- \\
28.1\end{array}$ & $\begin{array}{l}29.2- \\
90\end{array}$ & $\begin{array}{l}6.7- \\
32.8\end{array}$ & $\begin{array}{l}4.2- \\
65.6\end{array}$ & $\begin{array}{l}13019- \\
43900\end{array}$ & $\begin{array}{c}95.7- \\
553\end{array}$ & $\begin{array}{l}13.1- \\
42.1\end{array}$ & $\begin{array}{l}16.5- \\
25.2\end{array}$ & $\begin{array}{l}82- \\
267\end{array}$ & $\begin{array}{l}25- \\
78.6\end{array}$ & $\begin{array}{l}25.4- \\
131.8\end{array}$ & Present Study \\
\hline
\end{tabular}

240 Table 5 Heavy metal concentration $(\mathrm{mg} / \mathrm{kg})$ in Agricultural Soil of Punjab and worldwide

241

242

243

244 Spatial distribution of metals

245 Hotspot areas of contamination for the studied heavy metals were demarcated by using spatial distribution maps.

246 Fig. $\underline{2}, \underline{3}$ shows the spatial maps of AS and BS samples for the comparison studies. Similar metal distribution is

247 seen in case of BS samples except $\mathrm{Pb}, \mathrm{Co}$ and $\mathrm{Mn}$ showing different pattern. However, in the AS samples

248 distribution varies throughout the region and pattern observed is different for each metal. Generally $\mathrm{Pb}, \mathrm{As}, \mathrm{Co}$,

249 and $\mathrm{Sr}$ shows the similar distribution pattern with higher value in the eastern part of region. $\mathrm{Fe}, \mathrm{V}, \mathrm{Cr}, \mathrm{Mn}$ and $\mathrm{Ni}$

250 show the similar distribution with higher value in the western part. 


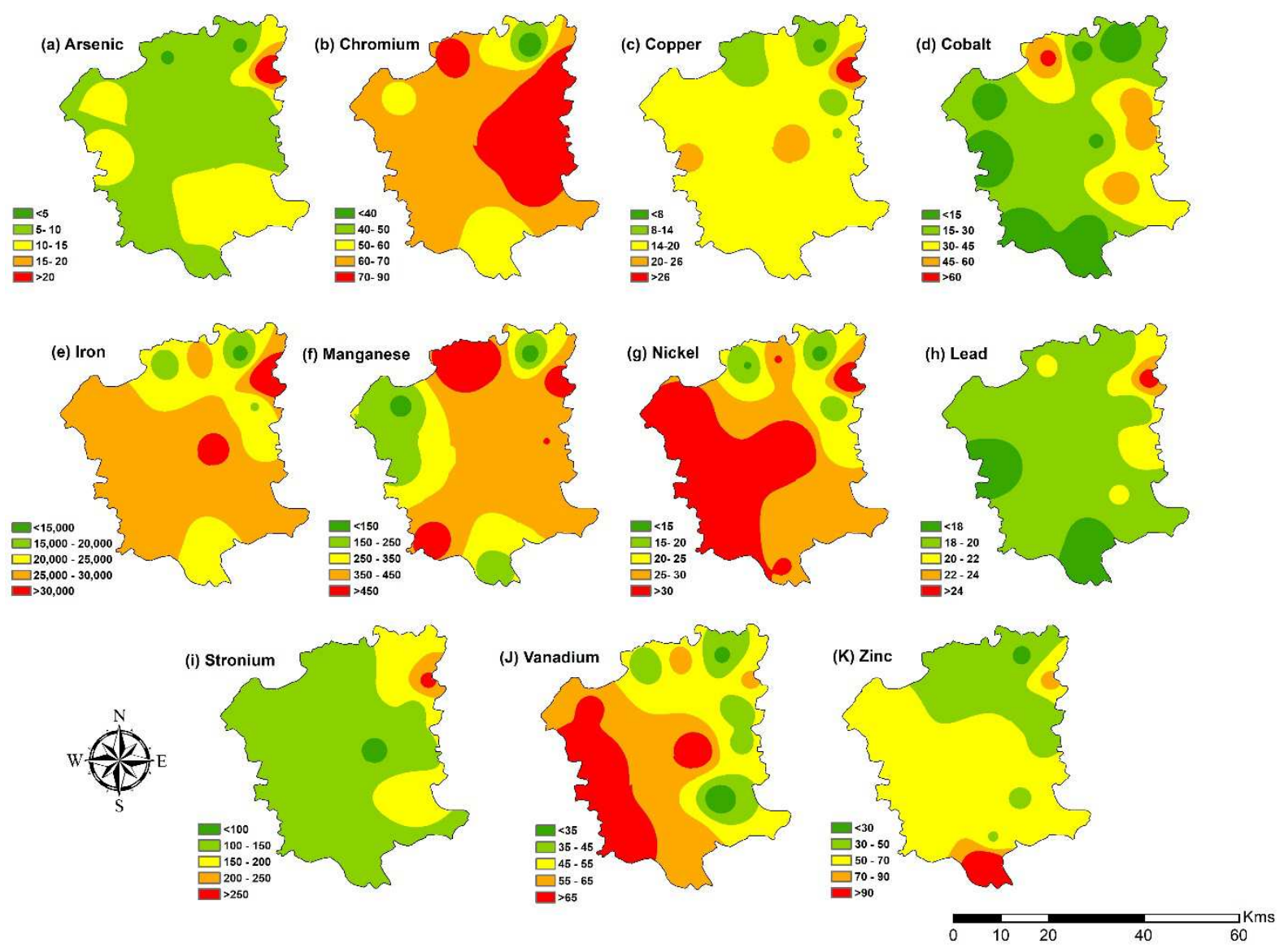

Fig. 2 Spatial distribution of heavy metals in the agricultural soil samples 

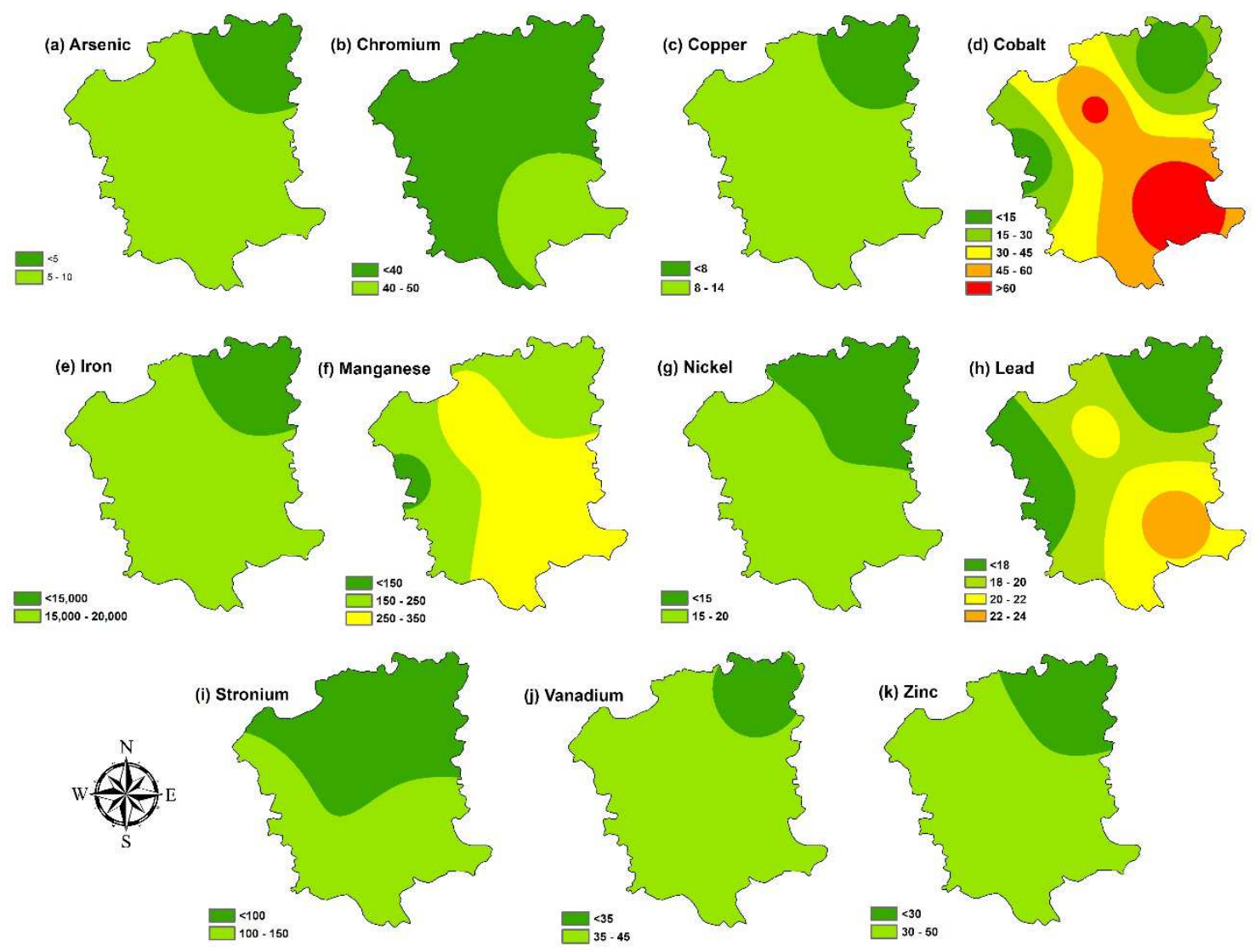

Fig. 3 Spatial distribution of heavy metals in the barren soil samples

Pollution Indices

Status of heavy metal pollution in the AS samples is estimated by using geo-accumulation Index and results are presented in Fig. 4a. It is observed that all the samples in the study region fall in the uncontaminated to moderately contaminated zone. In case of $\mathrm{As}, \mathrm{Cu}$ and $\mathrm{Zn}$ about $7.6 \%$ of samples are moderately contaminated belonging to class II however low level of contamination (class I) is observed in 76.9, 53.8, 61.5, 69.2 and 53.8\% of samples by $\mathrm{Cr}, \mathrm{Fe}, \mathrm{Mn}, \mathrm{Ni}$ and $\mathrm{V}$ respectively. Positive mean value of $\mathrm{I}_{\mathrm{geo}}$ in case of $\mathrm{As}, \mathrm{Cu}, \mathrm{Zn}, \mathrm{Cr}, \mathrm{Ni}$ indicates the contribution of anthropogenic activities for higher pollution levels (Tian et al., 2017).

Enrichment factor is also an efficient tool to identify the influence of anthropogenic activities on metal contamination in soil samples (Jiao et al., 2015). The average value of the EF shows the decreasing trend of $\mathrm{Cr}>\mathrm{Ni}>\mathrm{Cu}>\mathrm{Zn}>\mathrm{As}>\mathrm{Mn}>\mathrm{Sr}>\mathrm{V}>\mathrm{Pb}>\mathrm{Co}$. It is seen that $\mathrm{As}, \mathrm{Cu}, \mathrm{Co}, \mathrm{Ni}, \mathrm{Pb}$ and $\mathrm{V}$ shows minimum enrichment in all the AS samples with EF value $<2$. About $7.69 \%$ of samples shows moderate enrichment with respect to Mn, $\mathrm{Zn}$ and $\mathrm{Sr}$ however significant enrichment $(\mathrm{EF}>5)$ is seen in all the samples of $\mathrm{Cr}$ with $\mathrm{EF}$ value ranging from 612 (Fig. $\underline{4 b}$ ). Generally the input source of particular metal is considered to be crustal if its EF value is between 0.05 - 1.5, while the source is considered anthropogenic when the EF>1.5 (Rashed, 2010; Zhang \& Liu, 2002). On this basis, EF results confirm the influence of different anthropogenic activities on $\mathrm{Cr}$ to a greater extent and to a lesser extent on $\mathrm{Cr}, \mathrm{Mn}, \mathrm{Zn}, \mathrm{As}, \mathrm{Sr}$ and $\mathrm{Co}$. 


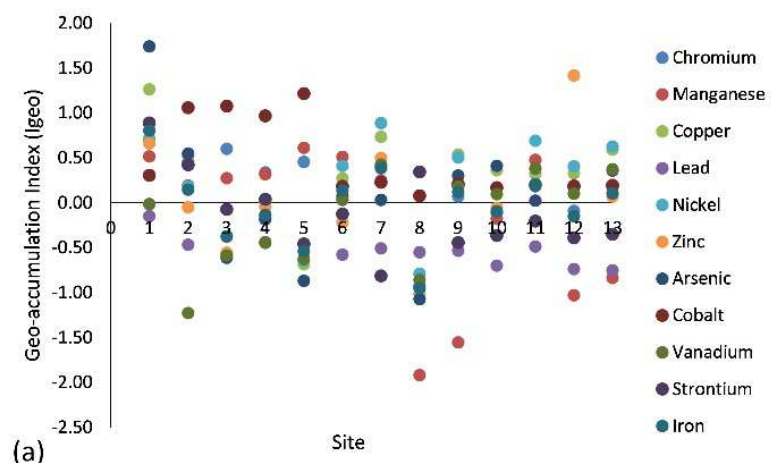

(a)
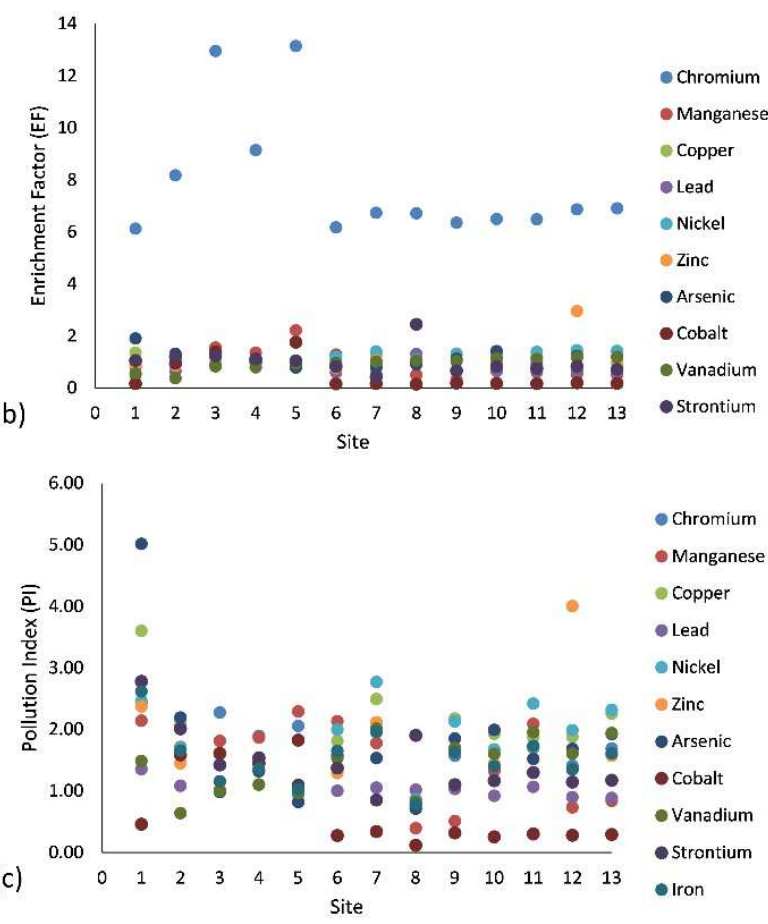

Fig. 4 Pollution Indices a) geo-accumulation index ( $\left.\mathrm{I}_{\text {geo }}\right)$ b) Enrichment Factor (EF) c) Pollution Index (PI)

Pollution index and Pollution load index are considered significant in calculating heavy metal pollution status of particular area (Maanan et al., 2015; Sungur \& Özcan, 2015). Results are shown in Fig. 4c. Mean PI values are found in the decreasing order of $\mathrm{Cu}>\mathrm{Ni}>\mathrm{As}>\mathrm{Cr}>\mathrm{Zn}>\mathrm{Fe}>\mathrm{Mn}>\mathrm{Sr}>\mathrm{V}>\mathrm{Pb}>\mathrm{Co}$. Average value of PI greater than 1 for all the elements except $\mathrm{Co}$ indicates moderate contamination in the study region. However few samples of $\mathrm{Cu}$, $\mathrm{Zn}$, As show the PI value $>3$ indicating considerable level of pollution. PLI value for all the heavy metals were calculated using PI value of each sample. PLI value lies in the range of 0.8 to 2.4 with a mean value of 1.51 . PLI value is greater than 1 for all the samples except one point (0.8) indicating moderate level of pollution throughout the study region. Ecological Risk Assessment Potential ecological risk factor $\left(\mathrm{E}_{\mathrm{r}}^{\mathrm{i}}\right)$ for individual elements is calculated for $\mathrm{As}, \mathrm{Cr}, \mathrm{Cu}, \mathrm{Ni}, \mathrm{Pb}, \mathrm{V}, \mathrm{Zn}$ in the present study and cumulative of all these heavy metals (RI) is shown in Table $\underline{6}$. Mean $\mathrm{E}_{\mathrm{r}}^{\mathrm{i}}$ for the toxic elements occurs in the order: $\mathrm{As}>\mathrm{Cu}>\mathrm{Ni}>\mathrm{Pb}>\mathrm{Cr}>\mathrm{V}>\mathrm{Zn}$. $\mathrm{E}_{\mathrm{r}}{ }^{\mathrm{i}}$ value is $<40$ for all the individual metals except that of $\mathrm{As}$ which show the highest ecological risk factor (50.18). RI value ranges from $24.33-97.51$ for all the samples with an average of 49.60, indicating low level of potential ecological risk in the area $(\mathrm{RI} \leq 150)$. 
291 Table 6 Potential ecological risk $\left(\mathrm{E}_{\mathrm{r}}^{\mathrm{i}}\right.$ and $\left.\mathrm{RI}\right)$ of heavy metals in the agricultural soil samples

\begin{tabular}{|c|c|c|c|c|c|c|c|c|c|}
\hline \multirow{2}{*}{ Site } & \multicolumn{7}{|c|}{ Potential ecological risk for single heavy metal $\left(\mathrm{E}_{\mathrm{i}}\right)$} & \multirow{2}{*}{$\begin{array}{l}\text { Total ecological risk } \\
\text { index (RI) }\end{array}$} & \multirow{2}{*}{ Pollution Level } \\
\hline & As & $\mathrm{Cr}$ & $\mathrm{Cu}$ & $\mathrm{Ni}$ & $\mathrm{Pb}$ & $\mathrm{V}$ & $\mathrm{Zn}$ & & \\
\hline 1 & 50.18 & 4.88 & 18.02 & 12.3 & 6.77 & 2.97 & 2.38 & 97.51 & Moderate \\
\hline 2 & 21.96 & 4.12 & 10.77 & 8.52 & 5.43 & 1.28 & 1.45 & 53.53 & Low \\
\hline 3 & 9.82 & 4.55 & 5.77 & 5.07 & 5.03 & 2 & 1.02 & 33.26 & Low \\
\hline 4 & 13.21 & 3.79 & 7.58 & 6.68 & 5.54 & 2.21 & 1.46 & 40.47 & Low \\
\hline 5 & 8.21 & 4.12 & 4.67 & 4.8 & 5.43 & 1.95 & 1.09 & 30.27 & Low \\
\hline 6 & 15.78 & 3.1 & 9.07 & 9.99 & 5.03 & 3.07 & 1.29 & 47.33 & Low \\
\hline 7 & 15.36 & 4.01 & 12.49 & 13.87 & 5.28 & 4.03 & 2.12 & 57.16 & Low \\
\hline 8 & 7.13 & 1.59 & 3.72 & 4.34 & 5.12 & 1.66 & 0.77 & 24.33 & Low \\
\hline 9 & 18.52 & 3.15 & 10.89 & 10.65 & 5.19 & 3.4 & 1.7 & 53.49 & Low \\
\hline 10 & 19.95 & 2.77 & 9.65 & 8.39 & 4.62 & 3.21 & 1.44 & 50.03 & Low \\
\hline 11 & 15.25 & 3.41 & 9.38 & 12.11 & 5.35 & 3.91 & 1.73 & 51.14 & Low \\
\hline 12 & 16.87 & 2.82 & 9.42 & 9.95 & 4.5 & 3.22 & 4.01 & 50.79 & Low \\
\hline 13 & 19.25 & 3.38 & 11.31 & 11.6 & 4.45 & 3.89 & 1.58 & 55.45 & Low \\
\hline
\end{tabular}

292

\section{Potential Human Health Risk}

294 Environment and human health are highly impacted by the heavy metal pollution. Thus human health risk has

295 been estimated and presented in terms of non-carcinogenic and carcinogenic health risks. Exposure to these heavy

296 metals is assessed for ingestion, inhalation and dermal contact. Non-carcinogenic health risk to the residents is

297 assessed for $\mathrm{As}, \mathrm{Cr}, \mathrm{Cu}, \mathrm{Ni}, \mathrm{Pb}$ and $\mathrm{Zn}$. The $\mathrm{ADD}$ values for ingestion (ADD Ingestion), inhalation ( $\left.\mathrm{ADD}_{\text {Inhalation }}\right)$ and

298 dermal contact $\left(\mathrm{ADD}_{\text {Dermal }}\right)$ for all the metals are used for calculations of health quotient (HQ) and health index

299 (HI). Results are presented in Table $\underline{Z}$ along with the minimum, maximum and mean values. ADD values for both

300 children and adult are in the order: $\mathrm{ADD}_{\text {Ingestion }}>\mathrm{ADD} \mathrm{Dermal}>\mathrm{ADD}$ Inhalation which is in coherence with the studies

301 carried out in other parts of India (Adimalla, 2020a; Adimalla \& Wang, 2018). HQ is found to be maximum for

302 As, accounting for $47.3 \%$ in adults and $47 \%$ in children of the total HI value, followed by $\mathrm{Cr}>\mathrm{Pb}>\mathrm{Ni}>\mathrm{Cu}>\mathrm{Zn}$ via

303 all the three pathways (Fig. 5). The computed HI values also follows the same order and are below 1 for all the

304 metals indicating negligible non-carcinogenic risk of heavy metals in the study region (USEPA, 2001). However

305 younger age group is at greater health risk with HI values an order of magnitude higher than that of adults. Thus

306 heavy metals in soil poses negligible non-carcinogenic health effect to the exposed population.

307 Table 7 Non-carcinogenic risk for adults and children via ingestion, inhalation and dermal pathways for heavy 308 metals

\begin{tabular}{|c|c|c|c|c|c|c|c|c|}
\hline & \multicolumn{5}{|c|}{ Adult } & \multicolumn{3}{|l|}{ Children } \\
\hline & $\mathrm{HQ}_{\text {Ingestion }}$ & $\mathrm{HQ}_{\text {Inhale }}$ & $\mathrm{HQ}_{\text {Dermal }}$ & $\mathrm{HI}$ & $\mathrm{HQ}_{\text {Ingestion }}$ & $\mathrm{HQ}_{\text {Inhale }}$ & $\mathrm{HQ}_{\text {Dermal }}$ & $\mathrm{HI}$ \\
\hline \multicolumn{9}{|c|}{ Arsenic } \\
\hline Minimum & $1.90 \mathrm{E}-02$ & $5.12 \mathrm{E}-06$ & $1.41 \mathrm{E}-03$ & $2.04 \mathrm{E}-02$ & $1.33 \mathrm{E}-01$ & $1.19 \mathrm{E}-06$ & $1.04 \mathrm{E}-04$ & $1.33 \mathrm{E}-01$ \\
\hline Maximum & $1.34 \mathrm{E}-01$ & $3.60 \mathrm{E}-05$ & 9.94E-03 & $1.44 \mathrm{E}-01$ & $9.37 \mathrm{E}-01$ & $8.40 \mathrm{E}-06$ & 7.31E-04 & $9.37 \mathrm{E}-01$ \\
\hline Mean & $4.75 \mathrm{E}-02$ & $1.28 \mathrm{E}-05$ & $3.53 \mathrm{E}-03$ & $5.10 \mathrm{E}-02$ & $3.32 \mathrm{E}-01$ & $2.98 \mathrm{E}-06$ & $2.59 \mathrm{E}-04$ & $3.33 \mathrm{E}-01$ \\
\hline \multicolumn{9}{|c|}{ Chromium } \\
\hline Minimum & $1.39 \mathrm{E}-02$ & $1.61 \mathrm{E}-04$ & $4.24 \mathrm{E}-04$ & $1.45 \mathrm{E}-02$ & $9.75 \mathrm{E}-02$ & $3.76 \mathrm{E}-05$ & $3.12 \mathrm{E}-05$ & $9.76 \mathrm{E}-02$ \\
\hline Maximum & $4.29 \mathrm{E}-02$ & $4.96 \mathrm{E}-04$ & $1.31 \mathrm{E}-03$ & $4.47 \mathrm{E}-02$ & $3.00 \mathrm{E}-01$ & $1.16 \mathrm{E}-04$ & $9.60 \mathrm{E}-05$ & $3.00 \mathrm{E}-01$ \\
\hline Mean & $3.09 \mathrm{E}-02$ & $3.57 \mathrm{E}-04$ & $9.40 \mathrm{E}-04$ & $3.22 \mathrm{E}-02$ & $2.16 \mathrm{E}-01$ & $8.33 \mathrm{E}-05$ & $6.92 \mathrm{E}-05$ & $2.16 \mathrm{E}-01$ \\
\hline \multicolumn{9}{|c|}{ Copper } \\
\hline
\end{tabular}




\begin{tabular}{|c|c|c|c|c|c|c|c|c|}
\hline Minimum & $2.42 \mathrm{E}-04$ & $2.67 \mathrm{E}-08$ & $7.01 \mathrm{E}-06$ & $2.49 \mathrm{E}-04$ & $1.69 \mathrm{E}-03$ & $6.22 \mathrm{E}-09$ & $1.80 \mathrm{E}-06$ & $1.69 \mathrm{E}-03$ \\
\hline Maximum & $1.17 \mathrm{E}-03$ & $1.29 \mathrm{E}-07$ & $3.40 \mathrm{E}-05$ & $1.21 \mathrm{E}-03$ & $8.20 \mathrm{E}-03$ & $3.01 \mathrm{E}-08$ & $8.75 \mathrm{E}-06$ & $8.21 \mathrm{E}-03$ \\
\hline Mean & $6.14 \mathrm{E}-04$ & $6.77 \mathrm{E}-08$ & $1.78 \mathrm{E}-05$ & $6.32 \mathrm{E}-04$ & $4.30 \mathrm{E}-03$ & $1.58 \mathrm{E}-08$ & $4.58 \mathrm{E}-06$ & $4.30 \mathrm{E}-03$ \\
\hline \multicolumn{9}{|c|}{ Nickel } \\
\hline Minimum & $9.42 \mathrm{E}-04$ & $1.04 \mathrm{E}-07$ & $1.06 \mathrm{E}-04$ & $1.05 \mathrm{E}-03$ & $6.60 \mathrm{E}-03$ & $2.35 \mathrm{E}-08$ & $7.82 \mathrm{E}-06$ & $6.61 \mathrm{E}-03$ \\
\hline Maximum & $3.01 \mathrm{E}-03$ & $3.32 \mathrm{E}-07$ & $3.40 \mathrm{E}-04$ & $3.35 \mathrm{E}-03$ & $2.11 \mathrm{E}-02$ & 7.53E-08 & $2.50 \mathrm{E}-05$ & $2.11 \mathrm{E}-02$ \\
\hline Mean & $1.98 \mathrm{E}-03$ & $2.18 \mathrm{E}-07$ & $2.23 \mathrm{E}-04$ & $2.20 \mathrm{E}-03$ & $1.38 \mathrm{E}-02$ & 4.94E-08 & $1.64 \mathrm{E}-05$ & $1.38 \mathrm{E}-02$ \\
\hline \multicolumn{9}{|c|}{ Lead } \\
\hline Minimum & $1.69 \mathrm{E}-02$ & $1.73 \mathrm{E}-07$ & $1.37 \mathrm{E}-03$ & $1.83 \mathrm{E}-02$ & $1.18 \mathrm{E}-01$ & $1.73 \mathrm{E}-07$ & $1.01 \mathrm{E}-04$ & $1.18 \mathrm{E}-01$ \\
\hline Maximum & $2.57 \mathrm{E}-02$ & 2.63E-07 & $2.09 \mathrm{E}-03$ & $2.78 \mathrm{E}-02$ & $1.80 \mathrm{E}-01$ & 2.63E-07 & $1.54 \mathrm{E}-04$ & $1.80 \mathrm{E}-01$ \\
\hline Mean & $1.98 \mathrm{E}-02$ & $2.02 \mathrm{E}-07$ & $1.61 \mathrm{E}-03$ & $2.14 \mathrm{E}-02$ & $1.38 \mathrm{E}-01$ & $2.02 \mathrm{E}-07$ & $1.18 \mathrm{E}-04$ & $1.39 \mathrm{E}-01$ \\
\hline \multicolumn{9}{|c|}{ Zinc } \\
\hline Minimum & $1.21 \mathrm{E}-04$ & $1.34 \mathrm{E}-08$ & $1.85 \mathrm{E}-05$ & $1.40 \mathrm{E}-04$ & $8.50 \mathrm{E}-04$ & $3.12 \mathrm{E}-09$ & $1.36 \mathrm{E}-06$ & $8.51 \mathrm{E}-04$ \\
\hline Maximum & $6.28 \mathrm{E}-04$ & $6.93 \mathrm{E}-08$ & $9.56 \mathrm{E}-05$ & $7.24 \mathrm{E}-04$ & $4.40 \mathrm{E}-03$ & $1.62 \mathrm{E}-08$ & 7.03E-06 & 4.40E-03 \\
\hline Mean & $2.66 \mathrm{E}-04$ & $2.93 \mathrm{E}-08$ & 4.04E-05 & $3.06 \mathrm{E}-04$ & $1.86 \mathrm{E}-03$ & $6.83 \mathrm{E}-09$ & $2.97 \mathrm{E}-06$ & $1.86 \mathrm{E}-03$ \\
\hline
\end{tabular}

309 HQ, Hazard Quotient; HI, Hazard Index
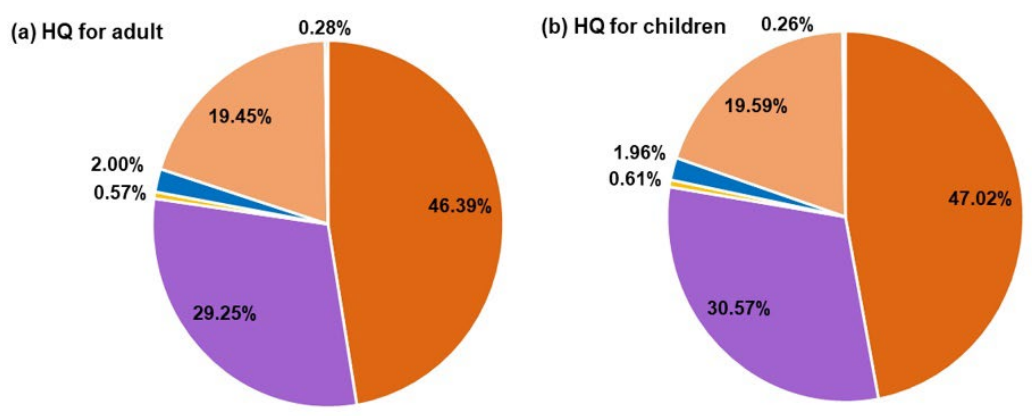

(c) TCR for adult

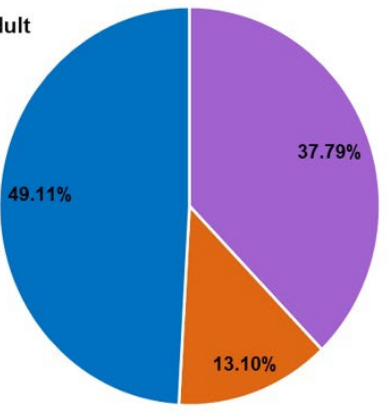

(d) TCR for children

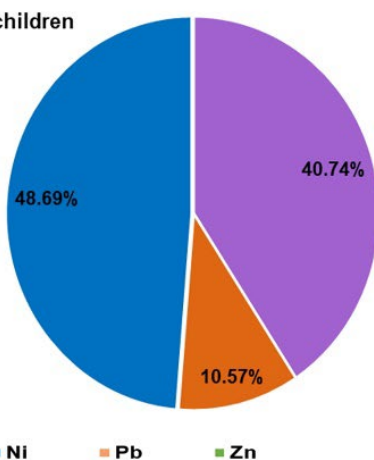

310

311 Fig. 5 Carcinogenic and non-carcinogenic risk contribution of each metal to the HQ and TCR. (a) HQ for adults

312 (b) HQ for children (c) TCR for adults (d) TCR for children

313 On the other hand, slope factor is only available for $\mathrm{As}, \mathrm{Pb}$ and $\mathrm{Ni}$ thus, carcinogenic health risk assessment is

314 carried out for these three heavy metals only and results are shown in Table $\underline{8}$ for all the three pathways. Non-

315 significant health risk ( $<1.0 \mathrm{E}-06)$ is observed via inhalation for both children and adult. Health risk via ingestion

316 and dermal contact is significant $(>1.0 \mathrm{E}-06)$ but not detrimental $(<1.0 \mathrm{E}-04)$ for both age groups. TCR follows the

317 order $\mathrm{Ni}>\mathrm{Cr}>\mathrm{As}$ for children and adult via the three pathways. Effects are comparatively more on children than

318 adults.

319 Table 8 Carcinogenic risk for adults and children via ingestion, inhalation and dermal pathways for heavy metals

\begin{tabular}{|c|c|c|c|c|c|c|c|c|}
\hline & \multicolumn{4}{|c|}{ Adult } & \multicolumn{4}{|c|}{ Children } \\
\hline & $\mathrm{CR}_{\text {Ingestion }}$ & $\mathrm{CR}_{\text {Inhale }}$ & $\mathrm{CR}_{\text {Dermal }}$ & TCR & $\mathrm{CR}_{\text {Ingestion }}$ & $\mathrm{CR}_{\text {Inhale }}$ & $\mathrm{CR}_{\text {Dermal }}$ & TCR \\
\hline \multicolumn{9}{|c|}{ Chromium } \\
\hline Minimum & $8.97 \mathrm{E}-06$ & $8.30 \mathrm{E}-08$ & $3.12 \mathrm{E}-06$ & $1.22 \mathrm{E}-05$ & $1.26 \mathrm{E}-05$ & $1.94 \mathrm{E}-08$ & $1.09 \mathrm{E}-05$ & $2.35 \mathrm{E}-05$ \\
\hline Maximum & $2.76 \mathrm{E}-05$ & $2.55 \mathrm{E}-07$ & $9.59 \mathrm{E}-06$ & $3.74 \mathrm{E}-05$ & $3.86 \mathrm{E}-05$ & $5.96 \mathrm{E}-08$ & $3.36 \mathrm{E}-05$ & 7.23E-05 \\
\hline Mean & $1.99 \mathrm{E}-05$ & $1.84 \mathrm{E}-07$ & $6.91 \mathrm{E}-06$ & $2.70 \mathrm{E}-05$ & $2.78 \mathrm{E}-05$ & $4.29 \mathrm{E}-08$ & $2.42 \mathrm{E}-05$ & $5.21 \mathrm{E}-05$ \\
\hline
\end{tabular}




\begin{tabular}{|c|c|c|c|c|c|c|c|c|}
\hline \multicolumn{9}{|c|}{ Arsenic } \\
\hline Minimum & $3.67 \mathrm{E}-06$ & $1.16 \mathrm{E}-12$ & 7.79E-08 & $3.75 \mathrm{E}-06$ & $5.14 \mathrm{E}-06$ & $2.71 \mathrm{E}-13$ & $2.73 \mathrm{E}-07$ & $5.41 \mathrm{E}-06$ \\
\hline Maximum & $2.58 \mathrm{E}-05$ & $8.16 \mathrm{E}-12$ & $5.48 \mathrm{E}-07$ & 2.64E-05 & $3.61 \mathrm{E}-05$ & $1.90 \mathrm{E}-12$ & $1.92 \mathrm{E}-06$ & $3.80 \mathrm{E}-05$ \\
\hline Mean & $9.16 \mathrm{E}-06$ & $2.90 \mathrm{E}-12$ & $1.94 \mathrm{E}-07$ & $9.35 \mathrm{E}-06$ & $1.28 \mathrm{E}-05$ & $6.76 \mathrm{E}-13$ & $6.8 \mathrm{E}-07$ & $1.35 \mathrm{E}-05$ \\
\hline \multicolumn{9}{|c|}{ Nickel } \\
\hline Minimum & $1.37 \mathrm{E}-05$ & $5.61 \mathrm{E}-09$ & 2.99E-06 & $1.67 \mathrm{E}-05$ & $1.92 \mathrm{E}-05$ & $1.31 \mathrm{E}-09$ & $1.05 \mathrm{E}-05$ & $2.97 \mathrm{E}-05$ \\
\hline Maximum & 4.39E-05 & $1.79 \mathrm{E}-08$ & $9.55 \mathrm{E}-06$ & $5.35 \mathrm{E}-05$ & $6.15 \mathrm{E}-05$ & 4.19E-09 & $3.34 \mathrm{E}-05$ & 9.49E-05 \\
\hline Mean & $2.88 \mathrm{E}-05$ & $1.18 \mathrm{E}-08$ & $6.26 \mathrm{E}-06$ & $3.51 \mathrm{E}-05$ & $4.03 \mathrm{E}-05$ & $2.75 \mathrm{E}-09$ & 2.19E-05 & $6.22 \mathrm{E}-05$ \\
\hline
\end{tabular}

320 CR, Carcinogenic risk; TCR, Total carcinogenic risk

321 Pollution Source Identification

322 Since the AS samples of the region are enriched in most of the HMs compared to the BS samples, thus it is

323 important to identify the potential source of contamination. Different multivariate statistical analysis were

324 employed to classify the geogenic or anthropogenic source of HM enrichment. Origin and migration of heavy

325 metals is known from the correlation among these elements (Suresh et al., 2011) thus pearson correlation analysis

326 are utilized for both the AS \& BS samples (Table 9). Significant positive correlation has been observed in most

327 of the heavy metals in the barren land. However, correlation is not the same between heavy metals in agricultural

328 areas. Positive correlation $(\mathrm{P}<0.01)$ has been found between $(\mathrm{Cr}-\mathrm{Mn}),(\mathrm{Cu}-\mathrm{Ni}),(\mathrm{Cu}-\mathrm{As}),(\mathrm{V}-\mathrm{Ni}),(\mathrm{Fe}-\mathrm{Cu}),(\mathrm{Fe}-$

$329 \mathrm{As}),(\mathrm{Sr}-\mathrm{Pb}),(\mathrm{Ni}-\mathrm{Fe})$. Significant correlation coefficient of HMs results from the same source or geochemical

330 processes controlling their behaviour ( $\mathrm{Li} \&$ Feng, 2012). Thus the correlation obtained shows that the $\mathrm{Cu}, \mathrm{Ni}, \mathrm{Fe}$

331 may have a common source. Similarly $\mathrm{Cr}-\mathrm{Mn}$ and $\mathrm{Pb}-\mathrm{Sr}$ might also have a common origin. It shows that

332 agricultural activities affect the correlation of heavy metals to a great extent.

333 Table 9 Pearson correlation of heavy metals is the AS \& BS samples

\begin{tabular}{|c|c|c|c|c|c|c|c|c|c|c|c|}
\hline \multicolumn{12}{|c|}{ Agricultural soil samples } \\
\hline & $\mathrm{Cr}$ & $\mathrm{Mn}$ & $\mathrm{Cu}$ & $\mathrm{Pb}$ & $\mathrm{Ni}$ & $\mathrm{Zn}$ & As & $\mathrm{Co}$ & $\mathrm{V}$ & $\mathrm{Fe}$ & $\mathrm{Sr}$ \\
\hline $\mathrm{Mn}$ & $0.70 * *$ & 1.000 & & & & & & & & & \\
\hline $\mathrm{Cu}$ & 0.444 & 0.148 & 1.000 & & & & & & & & \\
\hline $\mathrm{Pb}$ & $0.585 *$ & 0.537 & 0.458 & 1.000 & & & & & & & \\
\hline $\mathrm{Ni}$ & 0.199 & 0.063 & $0.83 * *$ & 0.127 & 1.000 & & & & & & \\
\hline $\mathrm{Zn}$ & 0.046 & -0.175 & 0.490 & -0.049 & 0.531 & 1.000 & & & & & \\
\hline As & 0.450 & 0.196 & $0.89 * *$ & $0.63 *$ & 0.543 & 0.380 & 1.000 & & & & \\
\hline Co & $0.59 *$ & 0.495 & -0.350 & 0.233 & $-0.57 *$ & -0.335 & -0.218 & 1.000 & & & \\
\hline $\mathrm{V}$ & -0.059 & -0.085 & 0.511 & -0.212 & $0.83 * *$ & 0.437 & 0.211 & -0.69 & 1.000 & & \\
\hline $\mathrm{Fe}$ & 0.546 & 0.356 & $0.96^{* *}$ & $0.58^{*}$ & $0.82 * *$ & 0.392 & $0.86^{* *}$ & -0.272 & 0.496 & 1.000 & \\
\hline $\mathrm{Sr}$ & 0.260 & 0.174 & 0.366 & $0.73 * *$ & -0.076 & -0.053 & $0.67 *$ & 0.090 & -0.449 & 0.386 & 1.000 \\
\hline \multicolumn{12}{|c|}{ Barren soil samples } \\
\hline & $\mathrm{Cr}$ & $\mathrm{Mn}$ & $\mathrm{Cu}$ & $\mathrm{Pb}$ & $\mathrm{Ni}$ & $\mathrm{Zn}$ & As & $\mathrm{Co}$ & $\mathrm{V}$ & $\mathrm{Fe}$ & $\mathrm{Sr}$ \\
\hline $\mathrm{Mn}$ & 0.746 & 1.000 & & & & & & & & & \\
\hline $\mathrm{Cu}$ & 0.943 & 0.565 & 1.000 & & & & & & & & \\
\hline $\mathrm{Pb}$ & 0.925 & 0.942 & 0.786 & 1.000 & & & & & & & \\
\hline $\mathrm{Ni}$ & 0.553 & -0.142 & 0.702 & 0.195 & 1.000 & & & & & & \\
\hline $\mathrm{Zn}$ & 0.947 & 0.494 & $0.971 *$ & 0.753 & 0.790 & 1.000 & & & & & \\
\hline As & 0.971 & 0.647 & $0.994 * *$ & 0.849 & 0.639 & $0.966^{*}$ & 1.000 & & & & \\
\hline Co & 0.939 & 0.915 & 0.850 & $0.987^{*}$ & 0.254 & 0.792 & 0.900 & 1.000 & & & \\
\hline $\mathrm{V}$ & 0.549 & -0.144 & 0.714 & 0.190 & $0.998 * *$ & 0.789 & 0.648 & 0.259 & 1.000 & & \\
\hline $\mathrm{Fe}$ & 0.940 & 0.515 & $0.995 * *$ & 0.758 & 0.758 & $0.998 *$ & $0.986 *$ & 0.817 & 0.766 & 1.000 & \\
\hline $\mathrm{Sr}$ & 0.554 & 0.057 & 0.469 & 0.328 & 0.735 & 0.665 & 0.468 & 0.270 & 0.690 & 0.546 & 1.000 \\
\hline
\end{tabular}

$334 *$ significant at level $<0.05, * *$ significant at level $<0.01$

335 Correlation of heavy metals is complex thus principal component analysis (PCA) and cluster analysis (CA) were

336 applied further to determine the possible source of HMs in the region. PCA is widely used to observe the

337 relationship among variables (Ma et al., 2016) and CA is usually combined with PCA for obtaining the variable 
338

339

340

341

342

343

344

345

346

347

348

349

350

351

352

353

groups and for results confirmation (Facchinelli et al., 2001). Table $\underline{10}$ shows the PCA results of heavy metals analysed and Fig. $\underline{6}$ shows the variation diagram. Three Principal Components were obtained for the analysed data with Eigen value greater than 1 and accounts for $86.56 \%$ of the total variance. PC1 accounts for the $37.59 \%$ of total variance and is strongly correlated with $\mathrm{Cu}, \mathrm{Ni}, \mathrm{V}, \mathrm{Zn}$ and $\mathrm{Fe}, \mathrm{PC} 2$ shows $26.35 \%$ of total variance with a heavy load of $\mathrm{Pb}$, As and Sr metals, PC3 explains $22.63 \%$ of total variance and heavily loaded with $\mathrm{Cr}, \mathrm{Mn}$ and V. CA results are shown as dendrogram in Fig. $\underline{7}$. The distance between the variables represents their similarity pattern. CA confirms the following clusters of variables:

Cluster I: $\mathrm{Cu}, \mathrm{Fe}, \mathrm{Ni}, \mathrm{V}, \mathrm{Zn}$

Cluster II: $\mathrm{Pb}, \mathrm{As}, \mathrm{Sr}$

Cluster III: Cr, Mn, Co

$\mathrm{Cu}, \mathrm{Ni}, \mathrm{Fe}, \mathrm{Zn}$ and $\mathrm{V}$ forms the largest group and can be ascribed to be of anthropogenic origin except iron (Martín et al., 2006). In general, copper content in soil is affected by both anthropogenic and geogenic activities (Martín et al., 2007). However in the current study, copper is found to be directly linked with the application of fungicides in the agricultural fields and is considered as marker of agricultural activities (Acosta et al., 2011). Also Zn is related with the agrochemicals used during cultivation (Martín et al., 2013; Nziguheba \& Smolders, 2008).

Table 10 Factor loadings of principal component analysis for the agricultural soil samples

\begin{tabular}{llll}
\hline & \multicolumn{2}{c}{ Component } \\
\cline { 2 - 4 } & PC1 & PC2 & PC3 \\
\hline $\mathrm{Cr}$ & 0.146 & 0.273 & 0.899 \\
$\mathrm{Cu}$ & 0.810 & 0.518 & 0.174 \\
$\mathrm{Mn}$ & -0.008 & 0.112 & 0.885 \\
$\mathrm{~Pb}$ & 0.034 & 0.778 & 0.470 \\
$\mathrm{Ni}$ & 0.967 & 0.062 & 0.070 \\
$\mathrm{Zn}$ & 0.638 & 0.048 & -0.139 \\
$\mathrm{As}$ & 0.542 & 0.790 & 0.145 \\
$\mathrm{Co}$ & -0.629 & -0.006 & 0.691 \\
$\mathrm{~V}$ & 0.895 & -0.329 & -0.88 \\
$\mathrm{Fe}$ & 0.776 & 0.512 & 0.340 \\
$\mathrm{Sr}$ & -0.152 & 0.968 & 0.027 \\
Eigenvalue & 4.85 & 44.12 & 44.12 \\
Total Variance $(\%)$ & 37.59 & 26.35 & 22.63 \\
Cumulative variance $(\%)$ & 37.59 & 63.94 & 86.56 \\
\hline
\end{tabular}

PC, Principal component

355 Second group comprising of $\mathrm{Pb}, \mathrm{Sr}$ and $\mathrm{As}$ can be associated with the geogenic component. Mean value of $\mathrm{Pb}$ in AS samples was also comparable to the background value of BS samples (Fig. $\underline{3}$ ). $\mathrm{Pb}$ and As are also linked with the contribution from industrial activities (Franco-Uría et al., 2009; Loska et al., 2004) however in the current study there is no such activity in the region and thus the elements cannot be considered to be of anthropogenic origin.

360 A group comprising of $\mathrm{Cr}, \mathrm{Mn}$ and $\mathrm{Co}$ is controlled by the geogenic component with some impact of anthropogenic factors. Many studies show the presence of these elements from the soil parental rocks (Chen et al., 2016; Salonen \& Korkka-Niemi, 2007; Xue et al., 2014). The study area is a part of alluvial plain and the soils are mainly formed by the weathering of nearby mountains forming parental rocks. Also in the current study manganese and cobalt values are higher in the backgrounds BS samples (Fig. $\underline{3}$ ), indicating its geogenic presence. 


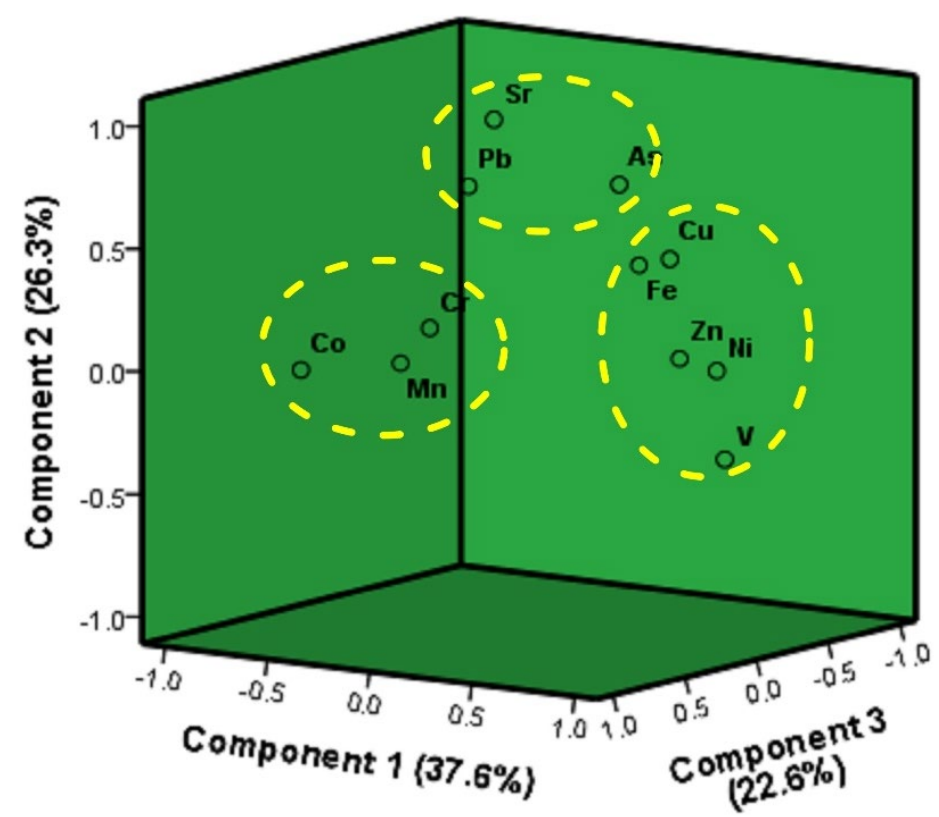

Fig. 6 PCA plot showing association of heavy metals in the agricultural soil

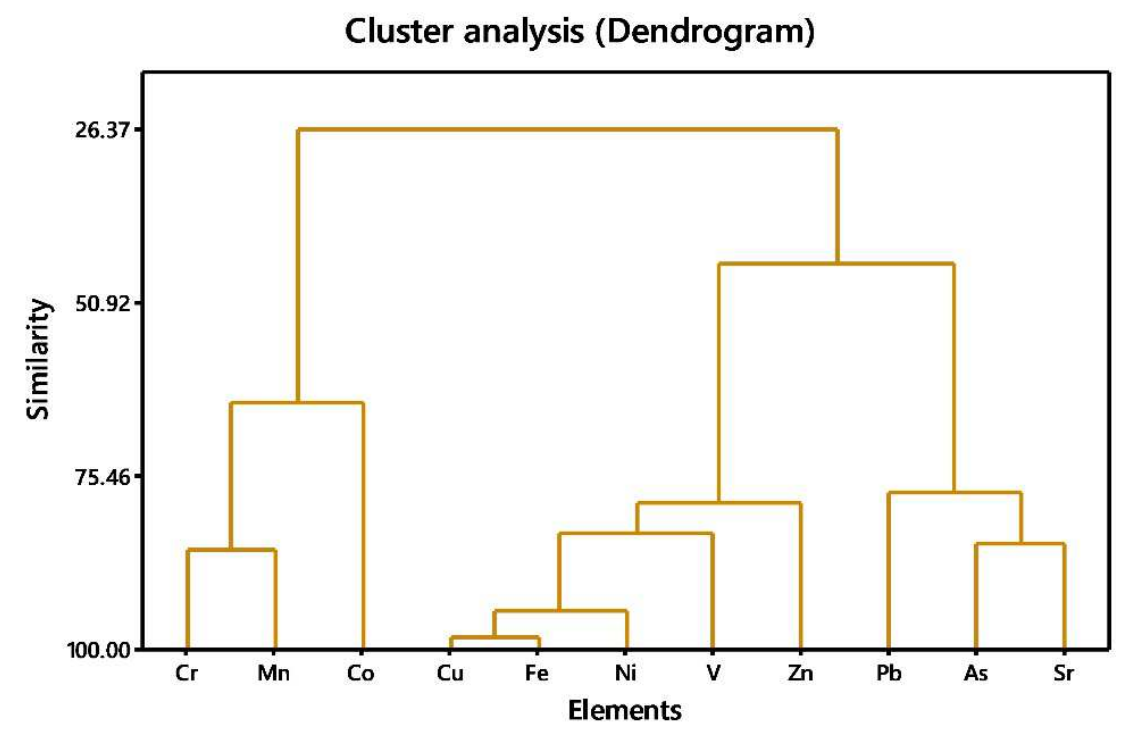

Fig. 7 Dendrogram of the Cluster analysis in the AS samples

\section{Conclusion}

Soil system of the region is polluted by the heavy metals in varying degree. When compared with the different national standards, $\mathrm{Cu}, \mathrm{Pb}, \mathrm{Mn}, \mathrm{Zn}$, As, Co exceeded the prescribed limits. Also significant difference was observed in the heavy metal content of AS and BS samples. All the metals were enriched in the AS samples except Co. Pollution indices highlight the significant role of $\mathrm{Cr}, \mathrm{Cu}, \mathrm{As}, \mathrm{Zn}, \mathrm{Mn}, \mathrm{Co}$ in the metal enrichment in agricultural areas indicating the contribution from anthropogenic activities. Multivariate statistical analysis of Pearson, PCA \& CA shows the three components (Cu, Ni, V, Zn, Fe), (Pb, As, Sr), (Co, Mn, Cr) and are correlated with the anthropogenic, geogenic and both the factors respectively. The results are also confirmed by the spatial distribution of heavy metals. Furthermore; the health risk posed by the studied heavy metal was determined first time in the soil of studied area. The carcinogenic and non-carcinogenic health risk were found to be within the 
acceptable limit however, children were at higher risk comparatively. Punjab is one of the largest contributor to the food basket of India and the increased content of HMs in the agricultural soil of the region, suggests increased input from the anthropogenic factors. Special attention should be paid to the highly enriched metals to protect the soil system from further accumulation of contaminants. The results would be valuable for the enactment of various policies to protect the health of well beings in the region along with the soil quality assessment.

\section{Acknowledgements}

Authors are thankful to the Science and Engineering Research Board (SERB), Department of Science \& Technology (DST), Government of India, New Delhi for providing the financial assistance. Authors would also like to thank Mr. Nikhil Patial for his assistance in field sample collection.

\section{References:}

Acosta, J., Faz, A., Martínez-Martínez, S., \& Arocena, J. (2011). Enrichment of metals in soils subjected to different land uses in a typical Mediterranean environment (Murcia City, southeast Spain). Applied Geochemistry, 26(3), 405-414.

Adimalla, N. (2020a). Heavy metals contamination in urban surface soils of Medak province, India, and its risk assessment and spatial distribution. Environmental geochemistry and health, 42(1), 59-75.

Adimalla, N. (2020b). Spatial distribution, exposure, and potential health risk assessment from nitrate in drinking water from semi-arid region of South India. Human and Ecological Risk Assessment: An International Journal, 26(2), 310-334.

Adimalla, N., \& Wang, H. (2018). Distribution, contamination, and health risk assessment of heavy metals in surface soils from northern Telangana, India. Arabian Journal of Geosciences, 11(21), 1-15.

Alloway, B. J. (2012). Heavy metals in soils: trace metals and metalloids in soils and their bioavailability (Vol. 22). Springer Science \& Business Media.

ATSDR (2004). Toxicological profile for cobalt (U.S. Department of Health and Human Services). http://www.astdr.cdc.gov/toxprofiles

Bhaskar, C. V., Kumar, K., \& Nagendrappa, G. (2010). Assessment of heavy metals in water samples of certain locations situated around Tumkur, Karnataka, India. E-Journal of chemistry, 7(2), 349-352.

Bhatti, S. S., Kumar, V., Singh, N., Sambyal, V., Singh, J., Katnoria, J. K., \& Nagpal, A. K. (2016). Physicochemical properties and heavy metal contents of soils and kharif crops of Punjab, India. Procedia Environmental Sciences, 35, 801-808.

Bhatti, S. S., Sambyal, V., \& Nagpal, A. K. (2016). Heavy metals bioaccumulation in Berseem (Trifolium alexandrinum) cultivated in areas under intensive agriculture, Punjab, India. SpringerPlus, 5(1), 1-11.

Bhuiyan, M. A., Parvez, L., Islam, M., Dampare, S. B., \& Suzuki, S. (2010). Heavy metal pollution of coal mine-affected agricultural soils in the northern part of Bangladesh. Journal of hazardous materials, 173(1-3), 384-392.

Burges, A., Epelde, L., \& Garbisu, C. (2015). Impact of repeated single-metal and multi-metal pollution events on soil quality. Chemosphere, 120, 8-15.

Castro-González, N. P., Calderón-Sánchez, F., Moreno-Rojas, R., Moreno-Ortega, A., \& Tamariz-Flores, J. V. (2017). Health risks in rural populations due to heavy metals found in agricultural soils irrigated with wastewater in the Alto Balsas sub-basin in Tlaxcala and Puebla, Mexico. International journal of environmental health research, 27(6), 476-486.

CGWB (2017). Central Ground Water Board Ministry of Water Resources, River Development and Ganga Rejuvenation Government of India. Ground Water Year Book Punjab and Chandigarh (UT).

Chandrasekaran, A., Ravisankar, R., Harikrishnan, N., Satapathy, K., Prasad, M., \& Kanagasabapathy, K. (2015). Multivariate statistical analysis of heavy metal concentration in soils of Yelagiri Hills, Tamilnadu, India-Spectroscopical approach. Spectrochimica Acta Part A: Molecular and Biomolecular Spectroscopy, 137, 589-600.

Chen, H., Teng, Y., Lu, S., Wang, Y., \& Wang, J. (2015). Contamination features and health risk of soil heavy metals in China. Science of the total environment, 512, 143-153.

Chen, H., Teng, Y., Lu, S., Wang, Y., Wu, J., \& Wang, J. (2016). Source apportionment and health risk assessment of trace metals in surface soils of Beijing metropolitan, China. Chemosphere, 144, 10021011. 
Cheng, Z., Chen, L.-J., Li, H.-H., Lin, J.-Q., Yang, Z.-B., Yang, Y.-X., Xu, X.-X., Xian, J.-R., Shao, J.-R., \& Zhu, X.-M. (2018). Characteristics and health risk assessment of heavy metals exposure via household dust from urban area in Chengdu, China. Science of the total environment, 619, 621-629.

Darwesh, O. M., \& Matter, I. A. (2021). Nanomaterials in the biological treatment of contaminated soil. In Nanomaterials for Soil Remediation (pp. 285-300). Elsevier.

Ennaji, W., Barakat, A., El Baghdadi, M., \& Rais, J. (2020). Heavy metal contamination in agricultural soil and ecological risk assessment in the northeast area of Tadla plain, Morocco. Journal of Sedimentary Environments, 5(3), 307-320.

EPA (1996). Method 3050B. Acid digestion of sediment, sludge and soil. Revision 2.

Facchinelli, A., Sacchi, E., \& Mallen, L. (2001). Multivariate statistical and GIS-based approach to identify heavy metal sources in soils. Environmental pollution, 114(3), 313-324.

Franco-Uría, A., López-Mateo, C., Roca, E., \& Fernández-Marcos, M. L. (2009). Source identification of heavy metals in pastureland by multivariate analysis in NW Spain. Journal of hazardous materials, 165(1-3), 1008-1015.

Gowd, S. S., Reddy, M. R., \& Govil, P. (2010). Assessment of heavy metal contamination in soils at Jajmau (Kanpur) and Unnao industrial areas of the Ganga Plain, Uttar Pradesh, India. Journal of hazardous materials, 174(1-3), 113-121.

Hakanson, L. (1980). An ecological risk index for aquatic pollution control. A sedimentological approach. Water research, 14(8), 975-1001.

Hani, A., \& Pazira, E. (2011). Heavy metals assessment and identification of their sources in agricultural soils of Southern Tehran, Iran. Environmental monitoring and assessment, 176(1), 677-691.

IARC (2012). Volume 100C: Monographs on the evaluation of carcinogenic risk to humans. Lyon, international agency for research on Cancer.

Imperato, M., Adamo, P., Naimo, D., Arienzo, M., Stanzione, D., \& Violante, P. (2003). Spatial distribution of heavy metals in urban soils of Naples city (Italy). Environmental pollution, 124(2), 247-256.

Jiang, Y., Chao, S., Liu, J., Yang, Y., Chen, Y., Zhang, A., \& Cao, H. (2017). Source apportionment and health risk assessment of heavy metals in soil for a township in Jiangsu Province, China. Chemosphere, 168, 1658-1668.

Jiao, X., Teng, Y., Zhan, Y., Wu, J., \& Lin, X. (2015). Soil heavy metal pollution and risk assessment in Shenyang industrial district, Northeast China. PloS one, 10(5), e 0127736.

Kelepertzis, E. (2014). Accumulation of heavy metals in agricultural soils of Mediterranean: insights from Argolida basin, Peloponnese, Greece. Geoderma, 221, 82-90.

Khorshid, M. S. H., \& Thiele-Bruhn, S. (2016). Contamination status and assessment of urban and non-urban soils in the region of Sulaimani City, Kurdistan, Iraq. Environmental Earth Sciences, 75(16), 1-15.

Krishna, A., \& Govil, P. (2007). Soil contamination due to heavy metals from an industrial area of Surat, Gujarat, Western India. Environmental monitoring and assessment, 124(1), 263-275.

Kuhad, M., Malik, R., Singh, A., \& Dahiya, I. (1989). Background levels of heavy metals in agricultural soils of Indo-Gangetic Plains of Haryana. J. Indian Soc. Soil Sci, 37, 700-705.

Kulhari, A., Sheorayan, A., Bajar, S., Sarkar, S., Chaudhury, A., \& Kalia, R. K. (2013). Investigation of heavy metals in frequently utilized medicinal plants collected from environmentally diverse locations of north western India. SpringerPlus, 2(1), 1-9.

Kumar, R., Mittal, S., Peechat, S., Sahoo, P. K., \& Sahoo, S. K. (2020). Quantification of groundwateragricultural soil quality and associated health risks in the agri-intensive Sutlej River Basin of Punjab, India. Environmental geochemistry and health, 42(12), 4245-4268.

Kumar, V., Sharma, A., Kaur, P., Sidhu, G. P. S., Bali, A. S., Bhardwaj, R., Thukral, A. K., \& Cerda, A. (2019). Pollution assessment of heavy metals in soils of India and ecological risk assessment: A state-of-theart. Chemosphere, 216, 449-462.

Lee, C. S.-1., Li, X., Shi, W., Cheung, S. C.-n., \& Thornton, I. (2006). Metal contamination in urban, suburban, and country park soils of Hong Kong: a study based on GIS and multivariate statistics. Science of the total environment, 356(1-3), 45-61.

Li, X., \& Feng, L. (2012). Multivariate and geostatistical analyzes of metals in urban soil of Weinan industrial areas, Northwest of China. Atmospheric environment, 47, 58-65.

Li, X., Lee, S.-1., Wong, S.-c., Shi, W., \& Thornton, I. (2004). The study of metal contamination in urban soils of Hong Kong using a GIS-based approach. Environmental pollution, 129(1), 113-124.

Liu, L., Zhang, X., \& Zhong, T. (2016). Pollution and health risk assessment of heavy metals in urban soil in China. Human and Ecological Risk Assessment: An International Journal, 22(2), 424-434.

Liyuan, Y., Ji, S., Zulu, Z., Qingyi, S., \& Yuxin, Z. (2003). Distribution and ecological risk assessment for heavy metals in superficial sediments of Nansihu Lake. Journal of Lake Sciences, 15(3), 252-256.

Loska, K., Wiechuła, D., \& Korus, I. (2004). Metal contamination of farming soils affected by industry. Environment international, 30(2), 159-165. 
Ma, X., Zuo, H., Tian, M., Zhang, L., Meng, J., Zhou, X., Min, N., Chang, X., \& Liu, Y. (2016). Assessment of heavy metals contamination in sediments from three adjacent regions of the Yellow River using metal chemical fractions and multivariate analysis techniques. Chemosphere, 144, 264-272.

Maanan, M., Saddik, M., Maanan, M., Chaibi, M., Assobhei, O., \& Zourarah, B. (2015). Environmental and ecological risk assessment of heavy metals in sediments of Nador lagoon, Morocco. Ecological Indicators, 48, 616-626.

Martín, J. A. R., Arias, M. L., \& Corbí, J. M. G. (2006). Heavy metals contents in agricultural topsoils in the Ebro basin (Spain). Application of the multivariate geoestatistical methods to study spatial variations. Environmental pollution, 144(3), 1001-1012.

Martín, J. A. R., Carbonell, G., Nanos, N., \& Gutiérrez, C. (2013). Source identification of soil mercury in the Spanish islands. Archives of environmental contamination and toxicology, 64(2), 171-179.

Martín, J. A. R., De la Cueva, A. V., Corbí, J. M. G., \& Arias, M. L. (2007). Factors controlling the spatial variability of copper in topsoils of the northeastern region of the Iberian Peninsula, Spain. Water, air, and soil pollution, 186(1), 311-321.

Muller, G. (1979). Heavy-metals in sediment of the Rhine-changes since 1971. Umschau in Wissenschaft und Technik, 79(24), 778-783.

Muszynska, E., \& Hanus-Fajerska, E. (2015). Why are heavy metal hyperaccumulating plants so amazing? BioTechnologia. Journal of Biotechnology Computational Biology and Bionanotechnology, 96(4).

NRC (1983). Risk assessment in the federal government: managing the process (National Research Council Edition). National Academies Press, Washington, DC.

Nziguheba, G., \& Smolders, E. (2008). Inputs of trace elements in agricultural soils via phosphate fertilizers in European countries. Science of the total environment, 390(1), 53-57.

Pan, L.-b., Ma, J., Wang, X.-1., \& Hou, H. (2016). Heavy metals in soils from a typical county in Shanxi Province, China: levels, sources and spatial distribution. Chemosphere, 148, 248-254.

Proshad, R., Islam, M., Kormoker, T., Bhuyan, M., Hanif, M., Hossain, N., \& Sharma, A. (2019). Contamination of heavy metals in agricultural soils: ecological and health risk assessment. $S F J$ Nanochem Nanotechnol. 2019; 2 (1), 1012.

Rashed, M. (2010). Monitoring of contaminated toxic and heavy metals, from mine tailings through age accumulation, in soil and some wild plants at Southeast Egypt. Journal of hazardous materials, 178(13), 739-746.

Rattan, R., Datta, S., Chhonkar, P., Suribabu, K., \& Singh, A. (2005). Long-term impact of irrigation with sewage effluents on heavy metal content in soils, crops and groundwater-a case study. Agriculture, ecosystems \& environment, 109(3-4), 310-322.

Rong, Y., Rui, S., \& Hong, Z. (2016). Evaluation on heavy metal contamination and its potential ecological risk in soil: A case study of nonferrous metal smelting zone in Wulatehouqi. Soils, 48(2), 314-321.

Salonen, V.-P., \& Korkka-Niemi, K. (2007). Influence of parent sediments on the concentration of heavy metals in urban and suburban soils in Turku, Finland. Applied Geochemistry, 22(5), 906-918.

Sarkar, B. (2002). Heavy metals in the environment. CRC press.

Singh, A., Sharma, C. S., Jeyaseelan, A., \& Chowdary, V. (2015). Spatio-temporal analysis of groundwater resources in Jalandhar district of Punjab state, India. Sustainable Water Resources Management, 1(3), 293-304.

Singh, S., \& Park, J. (2018). Drivers of change in groundwater resources: a case study of the Indian Punjab. Food Security, 10(4), 965-979.

SINGLA, D., SINGLA, A., KAUR, M., \& WALIA, D. S. (2021). Incidence of Malignant Diseases in Punjab: A Retrospective Study in a Tertiary Level Government Hospital in Punjab. Journal of Clinical \& Diagnostic Research, 15(3).

Solgi, E., Esmaili-Sari, A., Riyahi-Bakhtiari, A., \& Hadipour, M. (2012). Soil contamination of metals in the three industrial estates, Arak, Iran. Bulletin of environmental contamination and toxicology, 88(4), 634638.

Sungur, A., \& Özcan, H. (2015). Chemometric and geochemical study of the heavy metal accumulation in the soils of a salt marsh area (Kavak Delta, NW Turkey). Journal of Soils and Sediments, 15(2), 323-331.

Suresh, G., Ramasamy, V., Meenakshisundaram, V., Venkatachalapathy, R., \& Ponnusamy, V. (2011). Influence of mineralogical and heavy metal composition on natural radionuclide concentrations in the river sediments. Applied radiation and isotopes, 69(10), 1466-1474.

Sutherland, R. (2000). Bed sediment-associated trace metals in an urban stream, Oahu, Hawaii. Environmental geology, 39(6), 611-627.

Tian, K., Huang, B., Xing, Z., \& Hu, W. (2017). Geochemical baseline establishment and ecological risk evaluation of heavy metals in greenhouse soils from Dongtai, China. Ecological Indicators, 72, 510520 . 
Tomlinson, D., Wilson, J., Harris, C., \& Jeffrey, D. (1980). Problems in the assessment of heavy-metal levels in estuaries and the formation of a pollution index. Helgoländer meeresuntersuchungen, 33(1-4), 566575.

USEPA (1997). Exposure factors handbook, Volume 1: General factors. Washington, DC: U.S. Environmental Protection Agency, Office of Research and Development.

USEPA (1989). Risk assessment guidance for superfund, Volume 1: Human health evaluation manual (Part A) Office of Emergency and Remedial Response, Washington, DC.

USEPA (2001). Supplemental Guidance for Developing Soil Screening Levels for Superfund Sites. Office of Solid Waste and Emergency Response, Washington, DC.

USEPA (2002). Supplemental guidance for developing soil screening levels for superfund sites. Washington, DC: U. S. Environmental Protection Agency, Office of Emergency and Remedial Response.

USEPA (2011). Exposure factors handbook: National Center for Environmental Assessment, Office of Research and Development, Washington, DC 20460, EPA/ 600/R-09/052F.

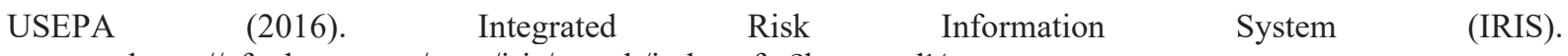
https://cfpub.epa.gov/ncea/iris/search/index.cfm?keyword $1 / 4$

Wei-Xin, L., ZHANG, X.-X., Bing, W., Shi-Lei, S., Yan-Song, C., Wen-Yang, P., Da-Yong, Z., \& CHENG, S.P. (2008). A comparative analysis of environmental quality assessment methods for heavy metalcontaminated soils. Pedosphere, 18(3), 344-352.

WHO (2004). Manganese and its compounds: Environmental aspects.

Wong, S., Li, X., Zhang, G., Qi, S., \& Min, Y. (2002). Heavy metals in agricultural soils of the Pearl River Delta, South China. Environmental pollution, 119(1), 33-44.

Wu, Q., Hu, W., Wang, H., Liu, P., Wang, X., \& Huang, B. (2021). Spatial distribution, ecological risk and sources of heavy metals in soils from a typical economic development area, Southeastern China. Science of The Total Environment, 780, 146557.

Xue, J.-1., Zhi, Y.-y., Yang, L.-p., Shi, J.-c., Zeng, L.-Z., \& Wu, L.-s. (2014). Positive matrix factorization as source apportionment of soil lead and cadmium around a battery plant (Changxing County, China). Environmental Science and Pollution Research, 21(12), 7698-7707.

Yang, Q., Li, Z., Lu, X., Duan, Q., Huang, L., \& Bi, J. (2018). A review of soil heavy metal pollution from industrial and agricultural regions in China: Pollution and risk assessment. Science of the total environment, 642, 690-700.

Zahran, M. A. E.-K., El-Amier, Y. A., Elnaggar, A. A., Mohamed, H. A. E.-A., \& El-Alfy, M. A. E.-H. (2015). Assessment and distribution of heavy metals pollutants in Manzala Lake, Egypt. Journal of Geoscience and Environment Protection, 3(06), 107.

Zhang, J., \& Liu, C. (2002). Riverine composition and estuarine geochemistry of particulate metals in Chinaweathering features, anthropogenic impact and chemical fluxes. Estuarine, coastal and shelf science, 54(6), 1051-1070.

Zhang, Z.-W., Xu, X.-R., Sun, Y.-X., Yu, S., Chen, Y.-S., \& Peng, J.-X. (2014). Heavy metal and organic contaminants in mangrove ecosystems of China: a review. Environmental Science and Pollution Research, 21(20), 11938-11950.

Zhu, Z., Sun, G., Bi, X., Li, Z., \& Yu, G. (2013). Identification of trace metal pollution in urban dust from kindergartens using magnetic, geochemical and lead isotopic analyses. Atmospheric environment, 77 , 9-15.

Zhuang, Z., Mu, H.-y., Fu, P.-n., Wan, Y.-n., Yu, Y., Wang, Q., \& Li, H.-f. (2020). Accumulation of potentially toxic elements in agricultural soil and scenario analysis of cadmium inputs by fertilization: A case study in Quzhou county. Journal of environmental management, 269, 110797. 
602 Funding

603 Corresponding author has received the research support from Science and Engineering Research Board (SERB),

604 Department of Science \& Technology (DST), Government of India, New Delhi (Project No. 000780/2017) for 605 the current work.

606 Competing Interests

607 All the authors declare that they have no relevant financial or non-financial interests to disclose.

608 Author contributions

609 All the authors have contributed equally to the study, conception and design of manuscript. All the authors have 610 read and approved the final manuscript. 